\title{
FUEL SPACER DEVELOPMENT
}

G.W. Richardson
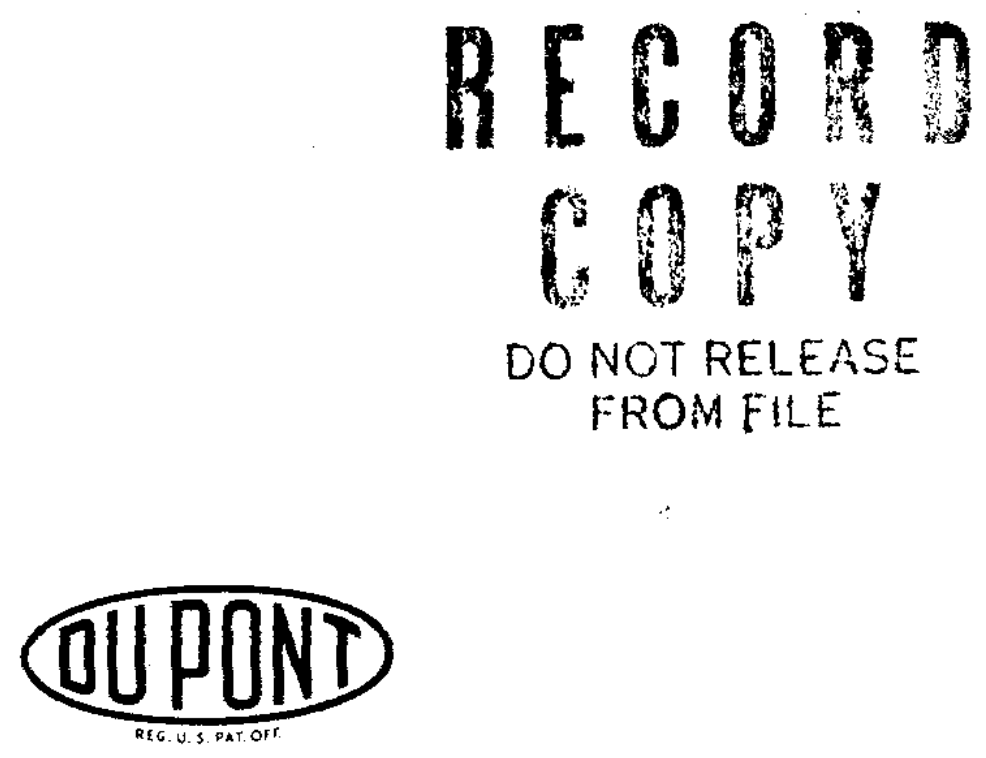

Savannah River Laboratory

Aiken, South Carolina 


\section{LEGAL NOTICE}

This report was prepared as an account of Government sponsored work. Nelther the United States, nor the Commission, nor any person acting on behalf of the Commission:

A. Makes any warranty or representation, expressed or implled, with respect to the accuracy, completeness, or usefulness of the information contained in this report, or that the use of any information, apparatus, method, or process disclosed in this report may not infringe privately owned rights; or

B. Assumes any liabilities with respect to the use of, or for dismages resulting from the use of any information, apparatus, method, or process disclosed in this report.

As used in the above, "person acting on behalf of the Commission" includes any employee or contractor of the Commission, or employee of such contractor, to the extent that such employee or contractor of the Commission, or employee of such contractor prepares, disseminates, or provides access to, any information pursuant to his employment or contract with the Commisston, or his employmest with such contractor.

Printed in USA. Price $\$ 2.00$

Avallable from the Clearinghouse for Federal Scientific

and Technical Information, National Bureau of Standards,

U. S. Department of Commerce, Springfield, Virginia 
E. I. du Pont de Nemours \& Company INCORPORATEO

SAVANNAH RIVER LabORATORY

Aiken, SOUth Carolina 29802

(TWX: 803.824.001B, TEL: 803.824.6331, WU: AUGUSTA, GA.)
C.W. J. WENDE, DIRECTOR

TECHNICAL DIVISION - AED

EXPLOSIVES DEPARTMENT

WILMINGTON h
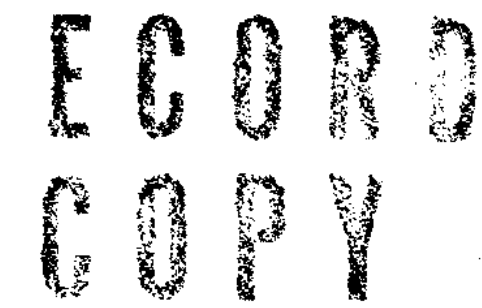

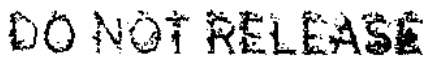

FROH FH

\section{DP-1002, FUEL SPACER DEVELOPMENT \\ by G. W. Richardson}

This report describes the results of the development work that was done at the Savannah River Laboratory in an effort to provide a reliable method for centering fuel tubes inside Zircaloy housings or within other fuel tubes in the program for development of power reactor fiel elements. The spacers that proved most reliable for providing sufficient support to minimize damage to the fuel were full-length ribs integral with either the fuel cladding or the housing tubes.

Other spacers that were investigated showed possibilities for successful application; however, the termination of the power fuel development program at SRI prevented a complete study of their suitability. Some of the alternate spacing methods that are described may be of interest to others for additional development and application in the maintaining of uniform coolant channels between concentric tubes.

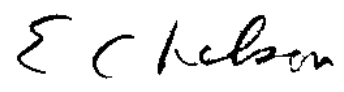

E. C. Nelson, Research Manager Reactor Engineering Division 
Reactor Technology (TID-4500, 45th Ed.)

\title{
FUEL SPACER DEVELOPMENT
}

by

George W. Richardson

\author{
Approved by \\ E. C. Nelson, Research Manager \\ Reactor Engineering Division
}

November 1965

\author{
E. I. DU PONT DE NEMOURS \& COMPANY \\ SAVANNAH RIVER LABORATORY \\ AIKEN, SOUTH CAROLINA \\ CONTRACT AT(07.2).1 WITH THE \\ UNITED STATES ATOMIC ENERGY COMMISSION
}




\section{ABSTRACT}

FuII-length Zircaloy ribs, permanently attached to Zircaloy-clad fuel or to Zircaloy housing tubes and sized to produce minimum clearances, provide the most reliable proven method of spacing large, concentric nuclear fuel pieces to ensure their integrity during power reactor operation. 


\section{CONTENTS}

\section{Page}

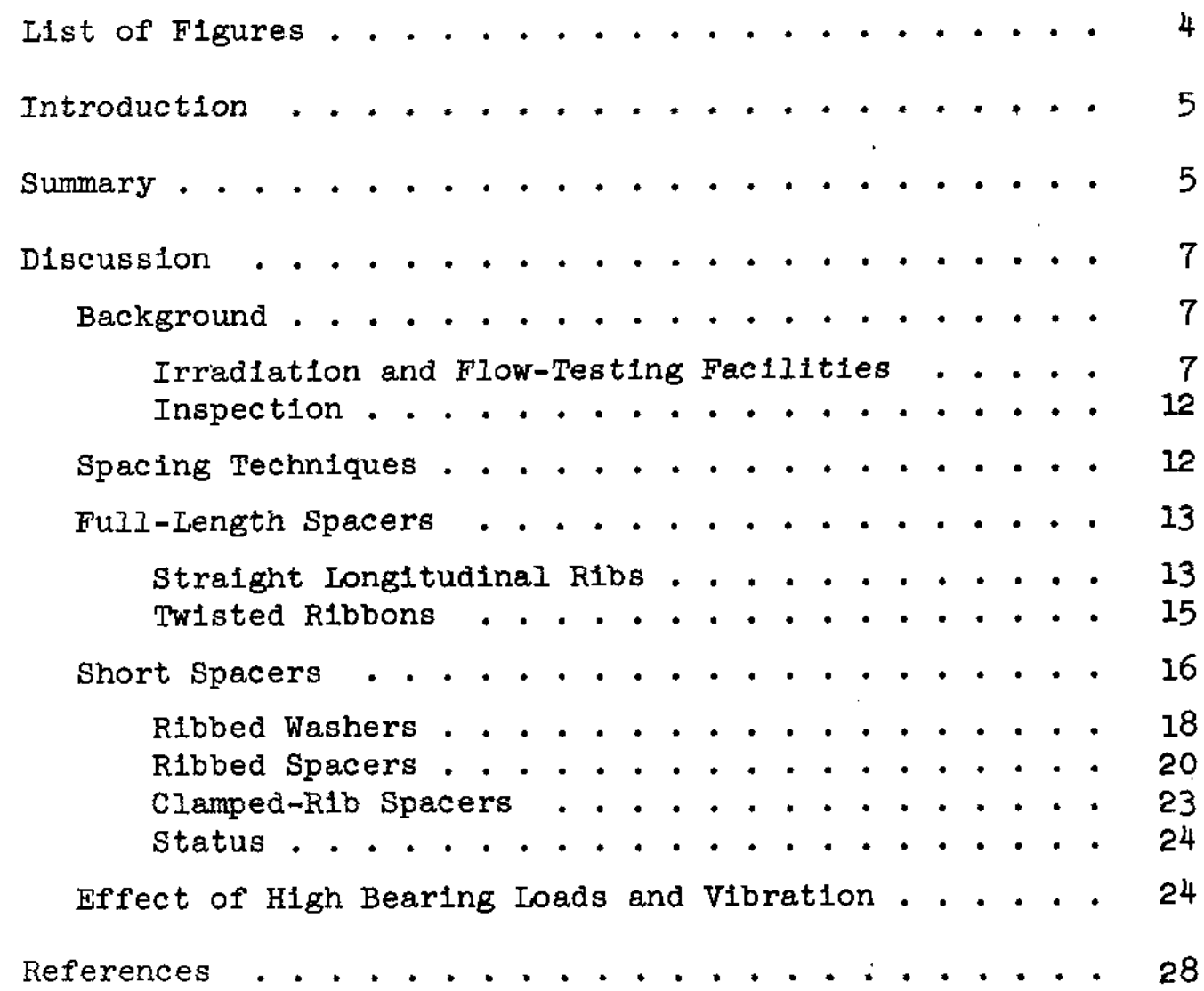

\section{List of Tables}

$\underline{\text { Table }}$

I Detalls of Test Assemblies . . . . . . . . 8

II Irradiation Tests . . . . . . . . . . . . 9

III Flow Tests . . . . . . . . . . . . . . . . 11 


\section{LIST OF FIGURES}

Figure

Page

1

Integrally Ribbed Zircaloy Housing Tube . . . . . . . 13

2 Welded Rib Zircaloy Housing Tube . . . . . . . . 14

3 Fuel Tube with Ribs Attached Directly to Cladding . . 14

4 Damage to Fuel Tube of Assembly OT-1-2 . . . . . . 15

5 Damage to Fuel Tube of Assemb1y 0T-1-4 . . . . . . . 15

6 Damage to Fuel Tube of Assembly OT-1-5 . . . . . . 15

$7 \quad$ Twisted Ribbon Spacers Attached to Fuel Tubes

of TWNT Assembly .............. i6

8 Penetration of Cladding by Twisted Ribbon Spacer . . 17

9 Wear Pattern in Zircaloy Cladding . . . . . . . 17

10 Ribbed Washer Used in SMT Assemblies . . . . . . 18

11 Penetration of SMT Housing by Ribbed Washer . . . . . 19

12 Circumferential Wear Bands on SMT Housing Tube , . . 19

13 Wear Bands and Grooves on SMT Components . . . . . . 19

14 Ribbed Spacer Used in SOT-4 Assembly . . . . . . 20

15 Portion of Fuel Column w1th Ribbed Spacers Attached . . 20

16 Dummy Inner Fuel Column . . . . . . . . . . . 21

17 Ribbed Spacer Attached to Dummy Fuel Plece . . . . . 21

18 Damage to Ribbed Spacer That Penetrated Cladding . . 22

19 Fuel Tube Failure Caused by Rib Penetration . . . . 22

20 Cladding Indentation Caused by Ribbed Spacer . . . . 22

21 Clamped-Rib Spacer . . . . . . . . . . . . 23

22 Clamped-Rib Spacers Positioned on Fuel Tube . . . . 24

23 Bolling Loop Bayonet in HWCTR . . . . . . . . . 25

24 Components for Bottom Fitting of Empty Housing in HWCTR Bayonet ............. 26

25 Damage to Bottom End Cap of HWCTR Bayonet . . . . . 27

26 Housing Tube That Penetrated Bottom of HWCTR Bayonet . 27 


\section{FUEL SPACER DEVELOPMENT}

\section{INTRODUCTION}

One of the principal objectives of the Du Pont program on heavywater-moderated power reactors was the development of low-cost, massive, Zircaloy-clad fuel elements. Efforts were concentrated on fuel tubes that could be assembled in a concentric array; a sultable spacing method for the tubes was a critical requirement for an assembly of this type. This report discusses the various spacing concepts that were evaluated in flow and irradiation test programs during the development of the nested tube fuel assembly.

\section{SUMMARY}

The most reliable proven spacing concept for maintaining the flow annuli of concentric fuel tubes in test irradiations conducted by the Savannah River Laboratory consisted of full-length longitudinal ribs, on the outside or inside surfaces of the various tubes, to provide maximum feasible bearing surface and to minimize the danger of vibration damage to the fuel. The ribs were either extruded as an integral part of the tubes or were attached by electron beam welding. (1) Flow tests and irradiation tests indicated that clearances between the mating components of the fuel assembly should be kept to a minimum. Diametral clearances of 0.030 inch were ample with longitudinal ribs extending the full length of the concentric tubes.

The major disadvantage of full-length extruded or welded ribs is high fabrication cost. During the fuel development program at the Savannah River Laboratory, a concerted effort was made to reduce the total cost through development of a more economical spacing technique. Although several spacing concepts were tested with varying degrees of success, none were proven to have the reliablilty of full-length ribs. It did appear possible that with additional effort a satisfactory alternate could be developed, but it is unlikely that the alternate would be as conservative a design as full-length ribs. The other spacing schemes investigated were, in chronological order:

- Twisted Ribbons - long bands of Zircaloy about $1 / 4$ inch wide and 0.030 inch thick were twisted, then spirally wrapped around the Zircaloy cladding of a fuel tube and welded to the tube at each end. This concept was unsuccessful because the ribbons vibrated in the turbulent coolant flowlng down the annuli, causing severe vibration damage to the cladding on the fuel tubes. 
- Ribbed Washer - a stainless steel investment casting comprising a 1/8-inch-thick washer, with four equaliy spaced ribs $(\sim 2-3 / 8$ inches long) attached. This type spacer was used only on short fuel tubes of natural uranium. A standard assembly contalned ten short fuel tubes in a single column with a ribbed washer at one end of each fuel tube to space it concentrically within the outer housing. This concept was unsuccessful because the tight fit of the washer ribs on the fuel tubes loosened during the test and allowed the ribbed washers to vibrate and rotate, causing considerable damage to the fuel and housing components.

- Ribbed Spacer - four ribs about $2-3 / 8$ inches long were welded to a $1 / 2-1$ nch-long ring whose wall thickness was equal to the wall of the fuel tube. This spacer differed from the "ribbed washer" in that it was attached to one end of each short fuel plece by four cap screws. An assembly containing seven short fuel tubes ( 15 inches long) of $\mathrm{UO}_{2}$ spaced in this manner was successfully flow tested for 57 days. However, a second assembly containing a full-length outer fuel tube and three short dummy inner fuel tubes ( 40 inches long), with ribbed spacers attached, was severely damaged after 97 days of testing. Further investigation of this spacing concept was planned to utilize increased rib contact area and decreased clearance between the ribs and the adjacent component, but the development program was terminated prior to actual testing.

- Clamped-Rib Spacer - four ribs, 2-I/2 inches long, were welded to a split sleeve (1-inch long $x 0.050$-inch wall) so that the ribs projected from both the inside and outside surfaces of the sleeve. The sleeve was positioned on the fuel tube, clamped snugly, and the split in the sleeve wall was welded. The inner diameter of the rib circle was thus clamped to the outside surface of the fuel tube, and the outer diameter of the ribs was against the inside of the housing which contained the tube. A flow test assembiy containing a 10-foot-long fuel tube with four of these spacers along its length was successfully tested for 97 days. A second test assembly containing two full-length fuel tubes in an unribbed housing and using clamped ribs to provide the spacing was flow tested for 125 days without damage to the fuel surfaces or to the housing tube. Continued testing of the clamped spacer concept was cancelled because of termination of the program. 


\section{DISCUSSION}

\section{ACKGROUND}

The over-all goal of the Du Pont development program on heavywater-moderated power reactors was to advance the technology of those reactors so that their use in large nuclear stations would permit generation of electricity at competitive costs. The principal phases of the program were: (I) irradiation of candidate fuels and other reactor components under power reactor conditions in the Heavy Water Components Test Reactor (HWCTR), (2) development of low-cost fuel tubes for use in large $\mathrm{D}_{2} \mathrm{O}$-moderated reactors, and (3) technical and economic evaluation of various $D_{2} O$-reactor design concepts.

To demonstrate low fuel cycle costs, Du Pont elected to develop relatively large tubular fuel elements 1.5 to 3.5 inches in diameter With wall thicknesses ranging from 0.15 to 0.30 inch. The core material in the fuel tubes was elther uranium oxide or uranium metal, clad with 0.015 to 0.025 inch of zircaloy. The assembly designs had two or three fuel tubes arranged concentrically within a Zircaloy housing or pressure tube, depending on the reactor concept. An important feature of this arrangement was the spacer system used to separate the fuel tubes from each other and from the housing or pressure tube.

The development of the nested-tube fuel assembly was concerned with the metallurgical evaluation of uranium metal and uranium oxide fuels for various operating parameters. This program required several different designs of test irradiation assemblies. Table I describes the types of fuel assemblies and their hydraulic conditions. Tables II and III list the results of visual examination of fuel assemblies after irradiation and after hydraulic tests.

\section{Irradiation and Flow-Testing Facilities}

The various fuel assemblies described in this report were irradiated of flow tested in facilities avaliable at the Savannah River Plant. The irradiation tests were performed in the Heavy Water Components Test Reactor (HWCTR) and the flow tests in the Power Flow Loop (PFI).

The HWCTR is a pressurized reactor that is cooled and moderated with heavy water. (2) The design conditions for the reactor were $1500 \mathrm{psi}$ at a temperature of $315^{\circ} \mathrm{C}$ and a maximum power estimated to be about $70 \mathrm{MW}$. The core consisted of a central test region, with 12 test fuel positions for assemblies with fuel columns up to 10 feet long, 
$\underline{\text { TABLE I }}$

Details of Test Assemblies

Zircaloy-Clad Fuel Tube

\begin{tabular}{|c|c|c|c|c|c|c|c|c|c|}
\hline $\begin{array}{c}\text { Assembiy } \\
\text { Type } \\
\end{array}$ & Core & $\begin{array}{l}\text { OD, } \\
\text { in. }\end{array}$ & $\begin{array}{l}\text { ID, } \\
\text { In. }\end{array}$ & $\begin{array}{l}\text { Length, } \\
\text { in. } \\
\end{array}$ & $\begin{array}{l}\text { Weight, } \\
\text { Ib } \\
\end{array}$ & $\begin{array}{c}\text { Fuel } \\
\text { Tubes/ } \\
\text { AssembIy }\end{array}$ & $\begin{array}{c}\text { Coolant } \\
\text { Flow, } \\
\text { gpm } \\
\end{array}$ & \multicolumn{2}{|c|}{$\begin{array}{c}\text { Annulus } \\
\text { Veloc1ty, ft/sec }\end{array}$} \\
\hline$S O T-I-X^{(b)}$ & Enriched $\mathrm{UO}_{2}$ & 2.06 & 1.47 & 14 & 4.7 & 7 & 240 & 13.4 & 20.6 \\
\hline SOT-2-X & Natural $\mathrm{UO}_{2}$ & 2.13 & 1.16 & 14 & 8.1 & 8 & 180 & 12.9 & 18.6 \\
\hline SOT-5-X & Natural $\mathrm{UO}_{2}$ & 2.13 & 1.08 & 24 & 7.9 & 7 & 200 & 26.5 & 20.3 \\
\hline SOT-6-X & Natural $\mathrm{UO}_{2}$ & 2.54 & 1.83 & 14 & 8.2 & 7 & 100 & 6.0 & 6.6 \\
\hline SOT-7-X & $\begin{array}{l}\text { Natural and } \\
\text { enriched } \mathrm{UO}_{2}\end{array}$ & 2.13 & 1.08 & 14 & 7.9 & 7 & 200 & 16.5 & 20.3 \\
\hline SOT-8-X & Enriched $\mathrm{UO}_{2}$ & 3.67 & 2.99 & 14 & 9.0 & 7 & 265 & 18.4 & 19.3 \\
\hline SOT-9-X & Enriched $\mathrm{UO}_{2}$ & 2.54 & 1.83 & 14 & 8.2 & 7 & 100 & 8.4 & 9.2 \\
\hline$S M T-1-X^{(c)}$ & $\begin{array}{l}\text { Natural } \\
\text { U Metal }\end{array}$ & 1.70 & 1.24 & $11 \frac{1}{4}$ & 6.5 & 10 & 80 & 6.1 & 7.9 \\
\hline$O T-1-x^{(d)}$ & Enrlched $\mathrm{UO}_{2}$ & 2.06 & 1.47 & 120 & 45 & 1 & 240 & 13.1 & 21.3 \\
\hline ThNT-X $\{$ e & $\begin{array}{l}\text { Natural } \\
\text { U Metal } \\
\text { Outer tube } \\
\text { Inner tube }\end{array}$ & $\begin{array}{l}2.06 \\
1.02\end{array}$ & $\begin{array}{l}1.70 \\
0.66\end{array}$ & $\begin{array}{l}120 \\
120\end{array}$ & $\begin{array}{l}60 \\
25\end{array}$ & $\begin{array}{l}1 \\
1\end{array}$ & 100 & 9.4 & $10.7^{(a)}$ \\
\hline TWO-1-X ${ }^{(f)}$ & $\begin{array}{l}\text { Natural } \\
\text { U Metal. }\end{array}$ & 2.06 & 1.70 & 120 & 60 & 1 & 120 & 10.5 & 10.7 \\
\hline 2ETWO-X (B) & $\begin{array}{l}2.1 \% \text { Enr } \\
\text { U Metal }\end{array}$ & 2.06 & 1.70 & 120 & 60 & 1 & 300 & 21.4 & 20.3 \\
\hline $\mathrm{RMT}-1-\mathrm{X}^{(\mathrm{h})}$ & $\begin{array}{l}\text { Natural } \\
\text { U Metal }\end{array}$ & 2.07 & 1.57 & 120 & 60 & 1 & 100 & 6.5 & 6.5 \\
\hline $3 \mathrm{EMT}-\mathrm{X}^{(1)}$ & $\begin{array}{l}3 \% \text { Enr } \\
\text { J Metal }\end{array}$ & 2.06 & 1.70 & 60 & 20 & 1 & 100 & 20.4 & 21.0 \\
\hline$T M T-1-x^{(j)}$ & $T h-I \frac{1}{2} \%$ U & 2.54 & i.84 & 121 & 90 & 1 & 100 & 18.1 & 19.5 \\
\hline
\end{tabular}

(a) Intermediate, annulus veloc1ty was $9.6 \mathrm{ft} / \mathrm{sec}$.

(b) SOT-1-X through SOT-9-X: Segmented Oxide Tubes - Fabrication Ser1es 1-9 - Assembly No. X

(c) SMT-1-X: Segmented Metal Tubes - Fabrication Series 1 - Asembly No. $X$

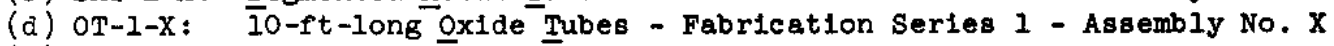

(e) TWNT-X: Thin-Walled Nested Tubes - Assembly No. X

(f) TWO-I-X: Th1n-W̄alled Outer metal tube - Fabrication Series 1 - Assembly No. X

(a) 2ETWO-X: $\overline{2}$.I\% Enrichē Thin-Walled Quter metal tube - Assemoly No. X

(h) RMT-1-X: Restrânt Metal Tubes - Fabrication Series 1 - Assembly No. $X$

(1) 3EMT-X: 3\% Enriched MetaI Tubes - Assembly No. X

(j) TMT-1-X: Thorium Metal Tube- Fabrication Series I - Assembly No. X 


\section{TABLE II}

\section{Irradiation Tests}

\begin{tabular}{|c|c|c|c|}
\hline $\begin{array}{c}\text { Assembly } \\
\text { Type } \\
\end{array}$ & $\begin{array}{l}\text { Operating } \\
\text { Time, } \\
\text { deys } \\
\end{array}$ & $\begin{array}{l}\text { Spacing } \\
\text { Concept } \\
\text { Used } \\
\end{array}$ & Postirradiation Inspection \\
\hline SOT-1-2 & 460 & (a) & Successful irradiation. \\
\hline SOT-1-3 & 215 & (a) & $\begin{array}{l}\text { Minor wear on two upper tubes of } \\
\text { column due to contact with housing } \\
\text { rlbs }(\sim 5 \text { mils }) \text {. }\end{array}$ \\
\hline SOT-1-4 & 275 & (a) & Successful Irradiation. \\
\hline SOT-2 -2 & 110 & (a) & $\begin{array}{l}\text { Fafled due to fuel tube sheath } \\
\text { collapse - no significant wear. }\end{array}$ \\
\hline $\operatorname{sos}-2-3$ & 98 & $|a|$ & Falled (same a.s soT-2-2). \\
\hline SOT $-5-2$ & 80 & (a) & $\begin{array}{l}\text { Falled due to sheath defect - no } \\
\text { slgnificant wear. }\end{array}$ \\
\hline SOT-6-2 & 182 & (a) & Successful 1rradiation. \\
\hline SOT-6-3 & 89 & (a) & Successfui irradiation. \\
\hline SOT-7 -2 & 27 & (a) & $\begin{array}{l}\text { Falied due to sheath defect - no } \\
\text { algniflcant wear. }\end{array}$ \\
\hline SOT $-8-2$ & 85 & (b) & Successful 1rradiation. \\
\hline SOT $-8-3$ & 85 & (b) & Successful 1rradietion. \\
\hline SoT-9-2 & 201 & $\{a\}$ & $\begin{array}{l}\text { Succeseful 1rradiation - no } \\
\text { gigniflcant rear. }\end{array}$ \\
\hline OT-1-2 & 328 & (a) & $\begin{array}{l}\text { Grooves in cladding caused by } \\
\text { vibration due to inlet oriflce. }\end{array}$ \\
\hline OT-1-3 & 101 & (a) & Falled - cause unknown. \\
\hline$O T-1-4$ & 186 & (a) & $\begin{array}{l}\text { Grooves in cladding caused by } \\
\text { vibration due to inlet orifice. }\end{array}$ \\
\hline OT $-1-5$ & 122 & (a) & $\begin{array}{l}\text { Deep grooves in cladding caused } \\
\text { by inlet orifice. }\end{array}$ \\
\hline OT-1-6 & 113 & (a) & Falled - not inspected. \\
\hline$O T-1-7$ & 222 & (a) & Successful Irradiation. \\
\hline
\end{tabular}

(a) Integraliy ribbed Zircaloy nousing tube.

(b) Welded-rib zircaloy housing tube. 


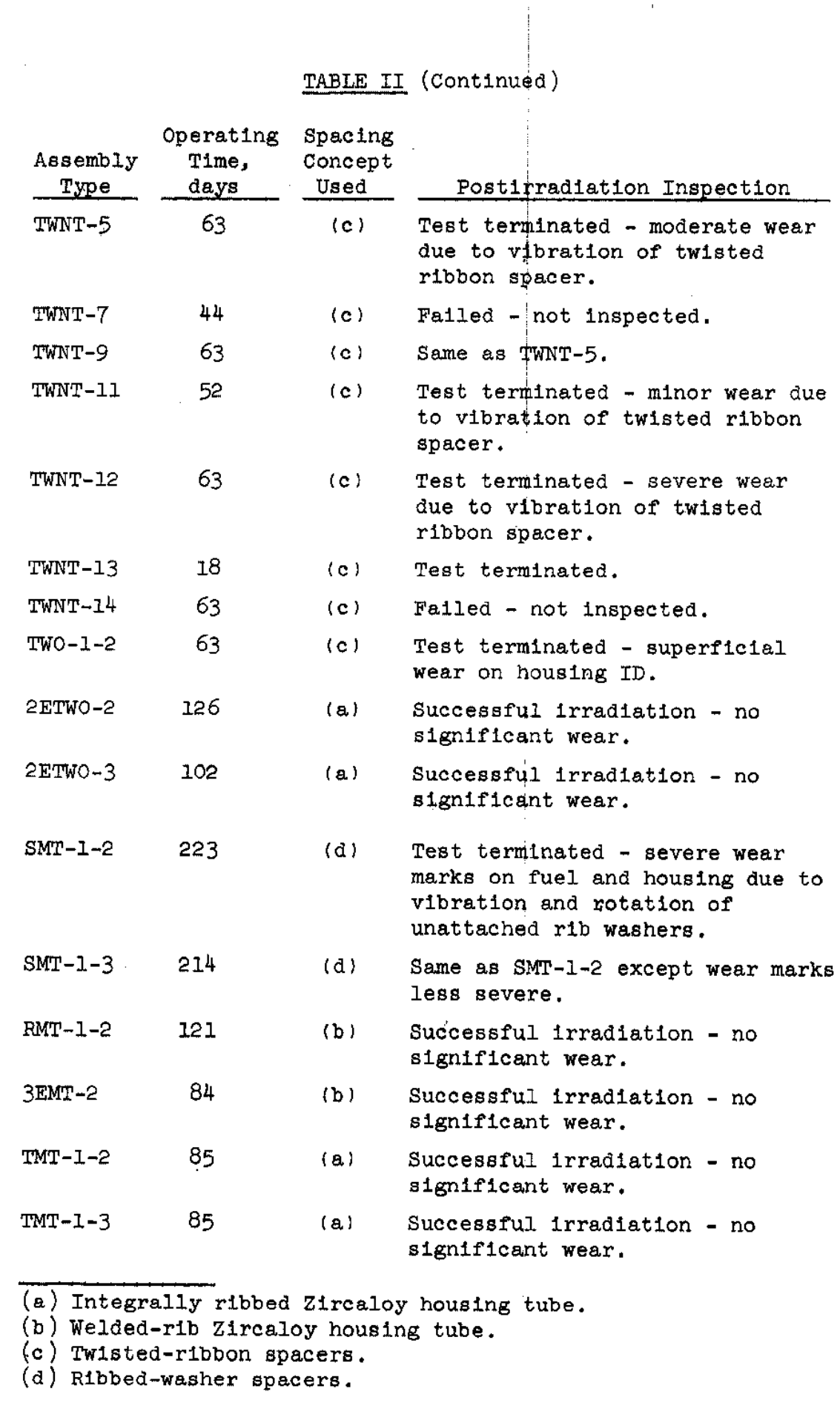




\section{TABLE III}

\section{Flow Tests}

\begin{tabular}{|c|c|c|c|}
\hline $\begin{array}{l}\text { Assembly } \\
\text { Type }\end{array}$ & $\begin{array}{l}\text { peratin } \\
\text { Time, } \\
\text { days }\end{array}$ & $\begin{array}{l}\text { Spacing } \\
\text { Concept } \\
\text { Used }\end{array}$ & Post1rradiation Inspection \\
\hline SOT-1-I & 161 & (a) & Successful flow test - no slgnlflcant wear. \\
\hline SOT-4-1 & 57 & (e) & Successful flow test - no slgnificant wear. \\
\hline SOT-6-1 & 200 & (a) & Successful flow test - no significant wear. \\
\hline SOT $-7-2$ & 83 & (a) & Successful plow test - no significant wear. \\
\hline SOT-8-1 & 97 & (b) & successful flow test - no slgniflcant wear. \\
\hline SOT-9-1 & 171 & (a) & Successful flow test - no significant wear. \\
\hline OT-1-1 & 241 & (a) & Successful flow test - no slgniflcant wear. \\
\hline OTC-1 & 66 & (f) & Successful flow test - no slgnificant wear. \\
\hline OT-1 & 97 & (e) & $\begin{array}{l}\text { Outer fuel tube failed - caused by penetra- } \\
\text { tion of inner cladding by ribbed spacer. }\end{array}$ \\
\hline TWO-1-1 & 112 & (c) & $\begin{array}{l}\text { Successful flow test - minor wear on } \\
\text { housing tube ID. }\end{array}$ \\
\hline 2ETWO-1-1 & 23 & (a) & Flow test terminated - no significant wear. \\
\hline TWNT-1 & 195 & (c) & $\begin{array}{l}\text { Successful flow test - minor wear caused by } \\
\text { ribbons at upper end of assembly. }\end{array}$ \\
\hline TWNT-2 & 115 & (c) & Successful slow test - no signiflcant wear. \\
\hline TWNT-3 & 109 & $(f)$ & Successful flow test - no significant wear. \\
\hline TWNT-LI-1 & 17 & (c) & $\begin{array}{l}\text { Outer fuel tube falled - caused by penetra- } \\
\text { tion of Inner cladding by twisted ribbon. }\end{array}$ \\
\hline TWNT-LL-2 & 14 & (c) & Same as TWNT-LL-1: \\
\hline 3EMT-1 & 183 & (b) & Successful flow test - no significant wear. \\
\hline SMT-1-1 & 185 & (d) & $\begin{array}{l}\text { Severe vibration damage - rigs penetrated } \\
\text { housing tube. }\end{array}$ \\
\hline TMT-1 & 97 & (a) & Successful flow test - no slgniflcant wear. \\
\hline
\end{tabular}

(a) Integrally ribbed Z1rcaloy housing tube.

(b) Welded-rib zircaloy housing tube.

(c) Twisted-ribbon spacer.

(d) Ribbed-washer spacer.

(e) R1bbed-spacer.

(f) Clamped-ring spacer. 
surrounded by a ring of driver assemblies containing enriched uranium fuel. Heavy water, which is pumped into the top part of the reactor vessel at a rate of about $10,000 \mathrm{gpm}$, flows down through the fuel assemblies, into the moderator space, and is returned to the coolant pumps .

The PFL is a pressurized, closed loop facllity for flow testing up to nine HWCTR-type fuel assemblies in filtered and delonized water of $\mathrm{pH} 7$, or filtered water at $\mathrm{pH} \mathrm{10}$, and a maximum temperature of $260^{\circ} \mathrm{C}$. Downflow or upflow coolant can be supplied to test assemblies with a maximum length of 17 feet. The loop is operated at $1000 \mathrm{psig}$ internal pressure with a total flow of $2800 \mathrm{gpm}$.

Inspection

Irradiated assemblies were disassembled in the underwater facilities at the Receiving Basin for Off-Site Fuel at Savannah River, $(3)$ and each component was visually examined for indications of damage during test. Suspect locations were photographed and, in many cases, were cut from a fuel plece for closer examination in the High Level Caves to evaluate possible damage.

Flow test assemblies were disassembled by hand at perlodic inspection intervals of 30 to 90 days and each component was visually examined for hydraulic or mechanical damage.

\section{SPACING TECHNIQUES}

Previous experience with the performance of fuel assemblies in the Savannah River reactors showed that full-length ribs, which were formed as an integral part of either an aluminum housing or the aluminum cladding on fuel pieces, were dependable for spacing fuel pieces to provide sufficient support without danger of mechanical damage because of vibration during operation. The high cost for providing zircaloy housings, or fuel cladding with integral ribs for use in the power reactor program prompted the investigation of simpler and cheaper spacing methods which might be suitable.

The spacing techniques considered for tubular components were divided into two basic groups; both were utilized during the fuel development program: (I) full-length spacers that positively position one tube with respect to the other over the entire mating length, and (2) short spacers positioned intermittently on a long tube or at one or both ends of short tubes. 
These groups were further divided according to the method by which the spacer was attached to the fuel or housing component: metallurgical attachment, such as welding, and the extrusion of integral ribs; and mechanical attachment, which included the use of cap screws and spring loading.

\section{FULL - LENGTH SPACERS}

\section{Straight Longitudinal Ribs}

Straight continuous ribs along the full length of a housing or fuel piece provide a minimum of disturbance for hydraulic flow while allowing the maximum bearing area for contact with the adjacent component. Irradiation and flow testing of more than 50 assemblies of Zircaloy-clad $\mathrm{UO}_{2}$ and uranium metal fuel tubes in integrally ribbed Zircaloy housings, and from which only minor vibration damage was seen, indicate that this is a satisfactory method of minimizing vibration damage in tubular fuel assemblies.

A zircaloy housing tube, in which the ribs were extruded as an integral part of the tube, is shown in Figure 1 . Extrusion characteristics of Zircaloy necessitated the slight rib projection on the OD opposite each rib, but this did not affect the design application for this housing.

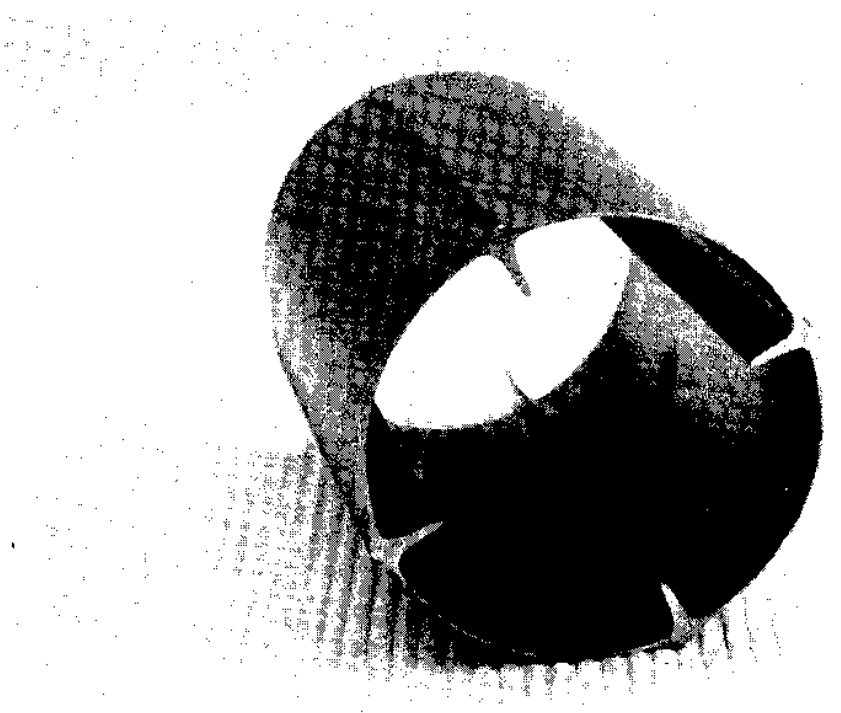

FIG. I INTEGRALLY RIBBED ZIRCALOY HOUSING TUBE 
The use of electron beam welding to attach four ribs to either the inner or outer surfaces of unribbed Zircaloy tubing produced reactor quality housings, as shown in Figure 2. This welding technique was also successful in attaching full-length ribs to fuel tubes, as shown in Figure 3.

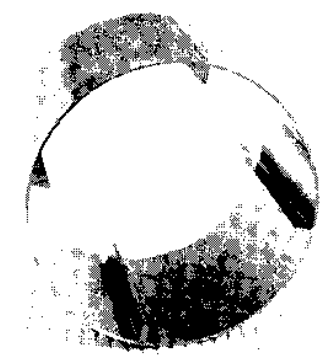

FIG. 2 WELDED RIB ZIRCALOY HOUSING TUBE

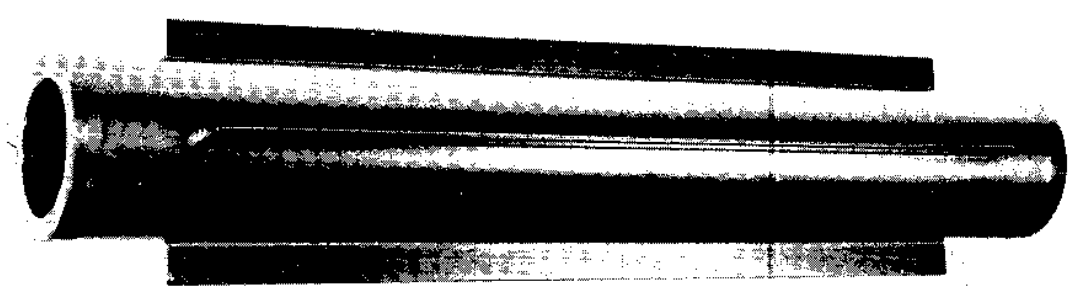

FIG. 3 FUEL TUBE WITH RIBS ATTACHED DIRECTLY TO CLADDING

Some vibration damage occurred in three irradiation assemblies, which utilized the extruded housings of Figure 1 (OT-l series, Table I), as the result of hydraulic turbulence in the reactor positions upstream from the three assemblies; the type of spacing was not the cause of damage. (4) In this case, the vibration of the fuel tubes resulted from eddies caused by a single 2-inch-diameter orifice through which the coolant passed just before it entered the top of the fuel assembly. The downstream jet from this large orifice impinged directly on a gripper fitting at the top of each fuel tube with sufficient force to vibrate the fitting and fuel tube. The damage to the outer cladding at the upper ends of the fuel tubes, resulting from contact with the ribs of the housing during 100 days of reactor operation, is shown in Figures 4, 5, and 6. The marks at the deepest penetration varied from 7 to 22 mils deep; in most cases each fuel tube was heavily worn by two adjacent ribs of the housing tube while the other two ribs contacted the fuel only lightly. Two other design features of these assemblies favored vibratory movement of the upper ends of the fuel tubes: 


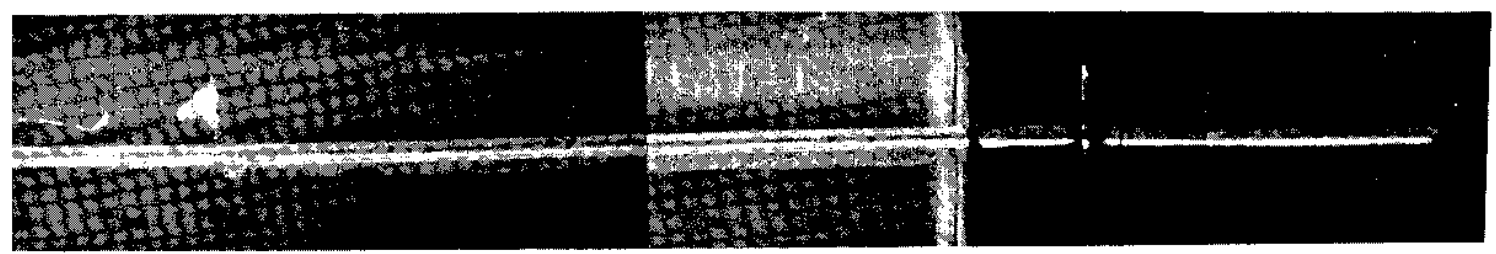

FIG. 4 DAMAGE TO FUEL TUBE OF ASSEMBLy OT-1-2

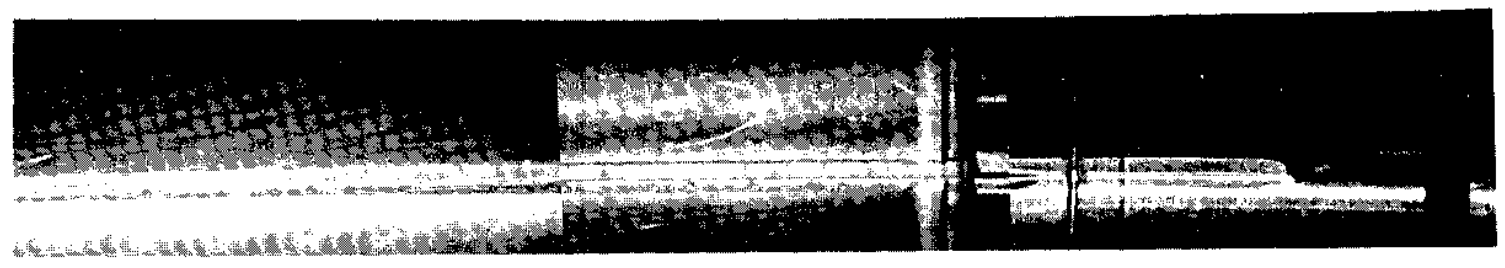

FIG. 5 DAMAGE TO FUEL TUBE OF ASSEMBLY OT - 1.4

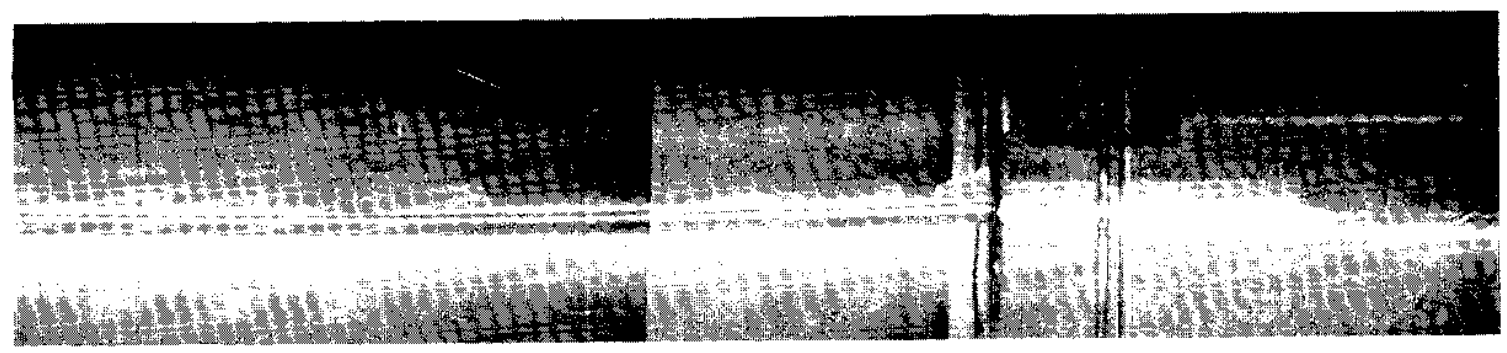

FIG. 6 DAMAGE TO FUEL TUBE OF ASSEMBLY OT. $1-5$

(a) Insufficient lateral support of the stainless steel fitting at the top of the fuel tube, and (b) excessive diametral clearance between the fuel and the rib circle of the housing (60-90 mils instead of the standard $30 \mathrm{mils}$ ).

\section{Twisted Ribbons}

Long bands of Zircaloy about $1 / 4$ inch wide were twisted into ribbons and then splrally wrapped around fuel tubes, as shown in Figure 7 . The ribbons were welded to only the upper and lower ends of the fuel tubes. The advantages of this spacer were simplicity in fabrication and flexibility in service, because the fuel could swell with minimum stress on the ribbons. The disadvantage was that the ribbons vibrated in the turbulent coolant flowing down the annuli, causing severe wear of the ribbons and serious damage to the fuel tubes both in flow tests and in the reactor. 


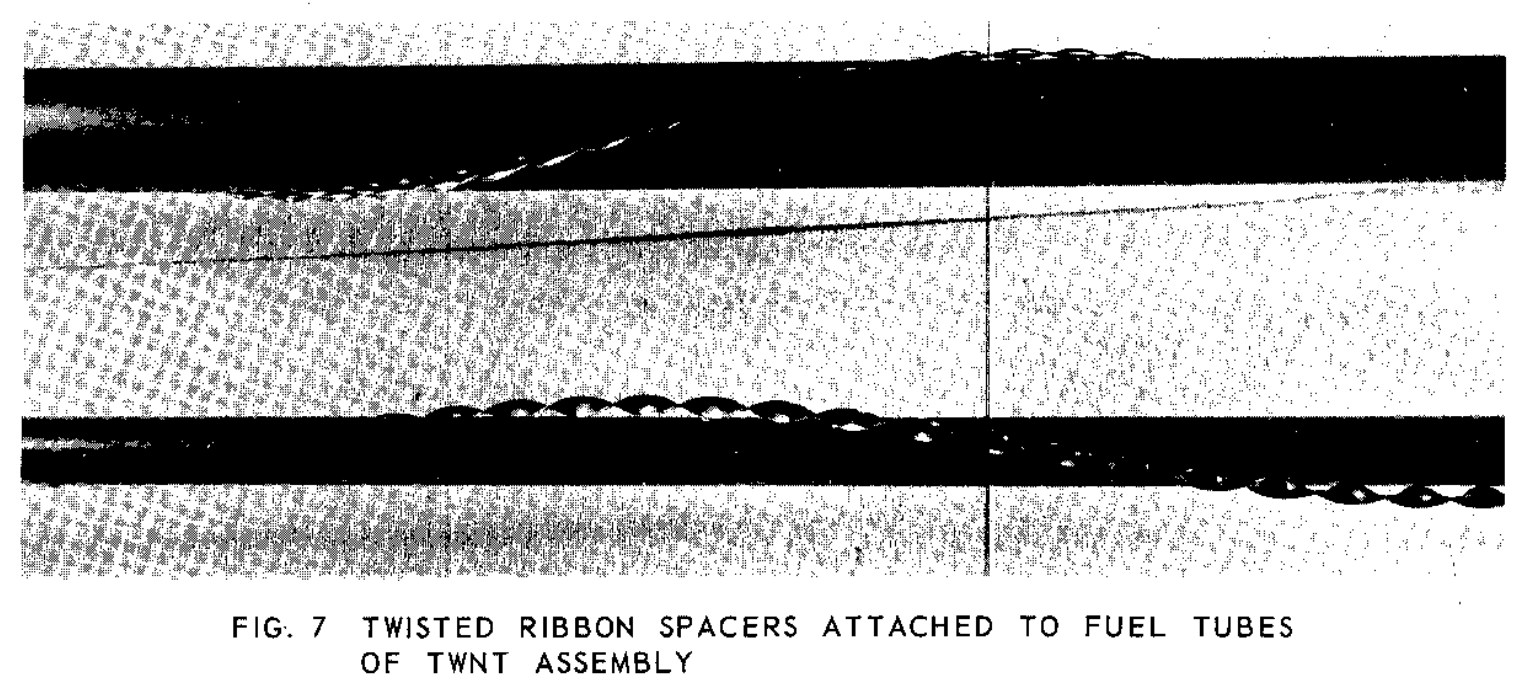

Six pairs of natural uranium fuel tubes with twisted ribbon spacers were irradiated in the HWCTR. In the flow test of a duplicate assembly which operated less than two months, the ribbon on the inner fuel tube wore through the inner cladding of the adjacent outer fuel tube, as shown in Figure 8. Almost simultaneously, two of the assemblies in the reactor failed prompting removal of all six assemblies. Postirradiation examination showed that in several assemblies there had been excessive motion between the spacers and the fuel tubes which produced wear patterns, shown in Figure 9, similar to those found in the failed flow test assembly. In a later flow test, the twisted ribbon was welded at 4-inch intervals to the surface of the inner tube; however, after 30 days of hydraulic testing the same wear patterns were on the ribbon and Inside the fuel tube. As a result of these experiences, twisted ribbons were not considered further.

\section{SHORT SPACERS}

The major portion of the fuel development program was concerned with the metallurgical aspects of uranium metal and uranium oxide. Short fuel tubes were fabricated for irradiation to expedite the evaluation of such variables as alloy, heat treatment, cladding thickness, temperature, exposure, density, and source of supply. The usual fuel assembly for test irradiation consisted of from six to ten short fuel tubes stacked in a single column inside a Zircaloy housing tube. The housing tubes were either extrusions with integral ribs or were unribbed. In unribbed housings, the coaxial alignment of the fuel column was provided by short stainless steel ribs that were attached to a washer located at one end of each fuel piece. Two variations in this spacer were tested. 


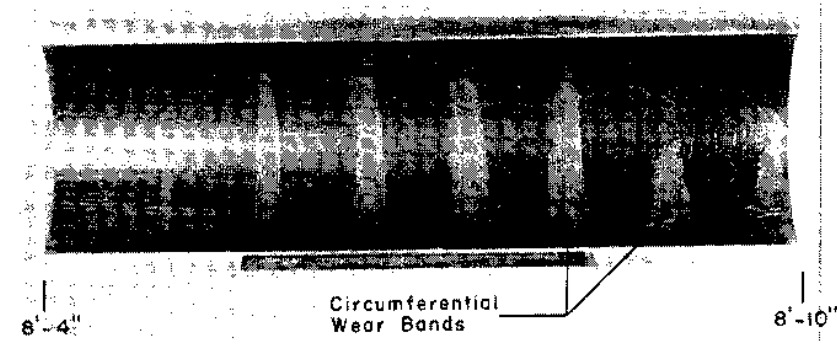

a. Side Opposite Cladding Break

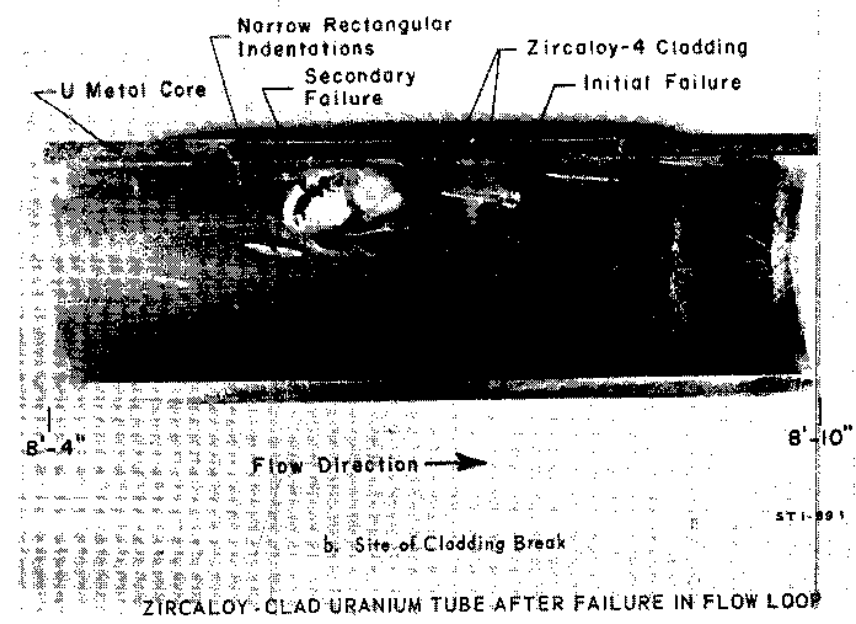

FIG. 8 PENETRATION OF CLADDING BY TWISTED RIBBON SPACER
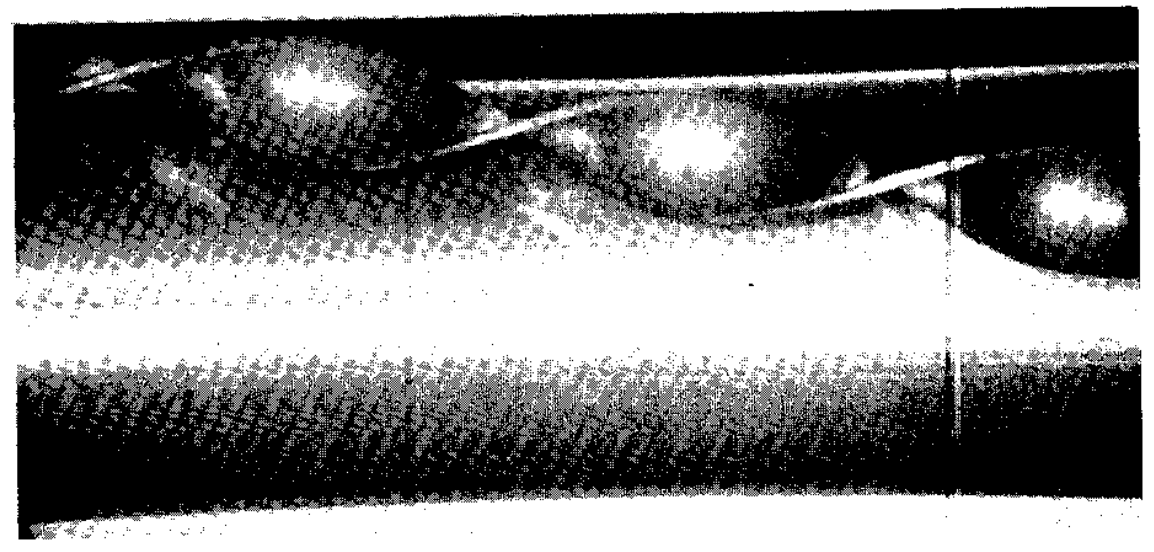

FIG. 9 WEAR PATTERN IN ZIRCALOY CLADDING 
Ribbed Washers

The first, a ribbed washer shown in Figure 10, consisted of a stainless steel investment casting comprising a $1 / 8$-inch-thick washer, with four equally spaced ribs ( $2-3 / 8$ inches long) attached. The inside diameter of the rib circle was machined to provide a tight fit on the fuel tubes, and the rib circle oD provided a maximum diametral clearance of $0.030 \mathrm{inch}$, or less, with the mating diameter of the adjacent tube.

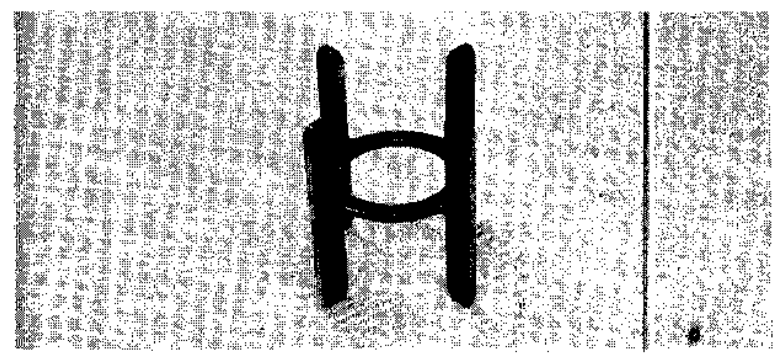

FIG. 10 RIBBED WASHER USED IN SMT ASSEMBLIES

Three assemblies were prepared: one for hydraulic test and two for irradiation in the HWCTR as the SMT-I-X assembly type described in Table I. Each contalned a fuel column of ten short fuel tubes with ribbed washers. During the 185-day flow test, the ribbed washers rotated around the axis of the fuel, apparently caused by the force of the coolant flowing down the annulus. The result was a loosening of the fit between the ribs and the fuel. which allowed the ribbed washers to move more freely inside the housing. The damage caused by the unrestrained washers is shown in Figures 11 through 13. The ribs penetrated the 0.035 -inch wall of the Zircaloy housing tube at several locations and the rotation of the washers caused wear bands on the housing and fuel pieces at all locations. The irradiation testing of the two similar assemblies was continued for several months following the flow test failure with intermittent examination of the assemblies to determine if similar damage was occurring in the reactor. The Irradiation of assembly SMT-1-2 was terminated when evidence of washer rotation and $r i b$ wear into the housing indicated the possibility of a housing break which might endanger the fuel or reactor operation. 


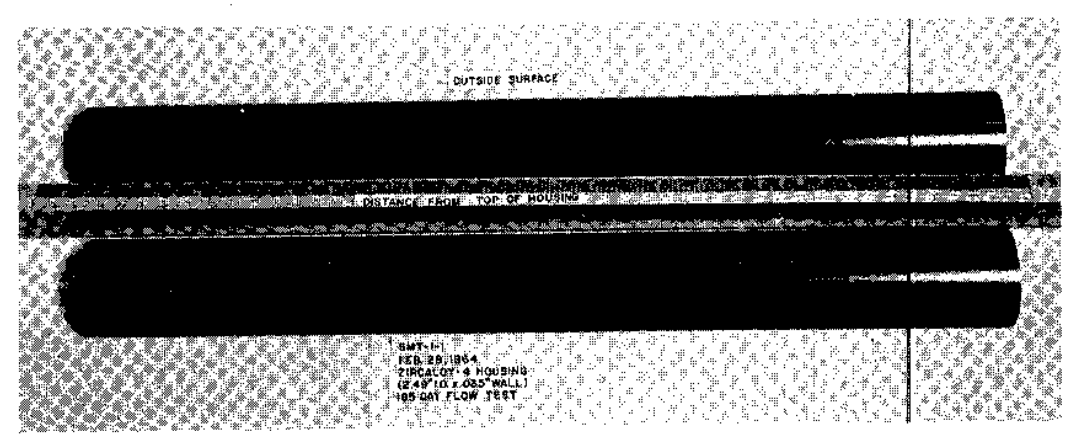

FIG. II PENETRATION OF SMT HOUSING BY RIBBED WASHER

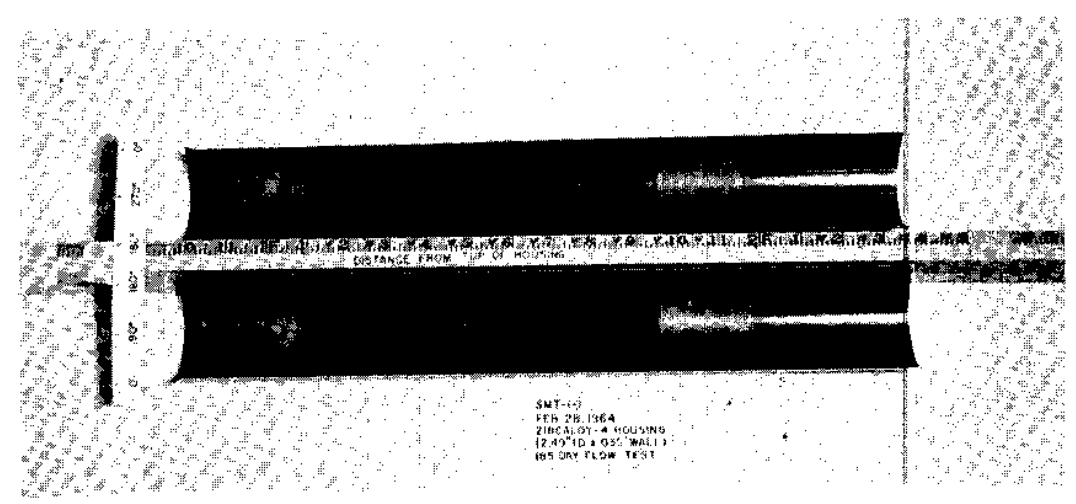

FIG. 12 CIRCUMFERENTIAL WEAR BANDS ON SMT HOUSING TUBE

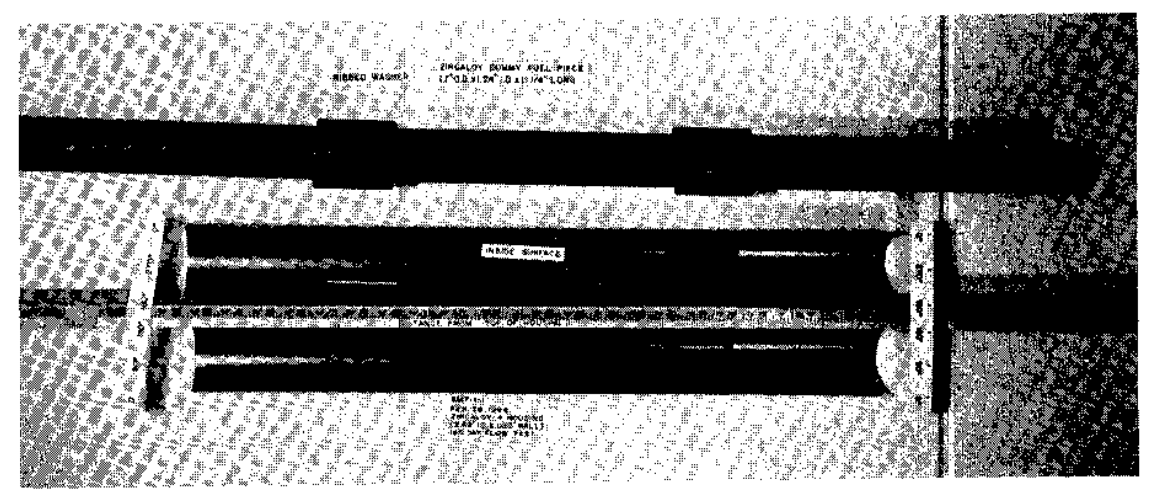

FIG. 13 WEAR BANDS AND GROOVES ON SMT COMPONENTS 


\section{Ribbed Spacers}

The second variation was a stainless-steel-ribbed spacer firmly attached to one end of each short fuel piece to eliminate the possibility of rotation or vibration of the spacer with reference to the fuel.

A typical ribbed spacer, shown in Figure 14, consisted of a $1 / 2$-inch-long ring, with $O D$ and ID equal to those of the fuel tube, to which four equally spaced ribs ( 2-3/8 inches long) were welded. The rib circle OD provided a maximum diametral clearance of 0.030 inch, or less, with the mating diameter of the adjacent tube. Each ribbed spacer was firmly attached to a fuel tube by four socket-head cap screws. A portion of the typical fuel column is shown in Flgure 15.

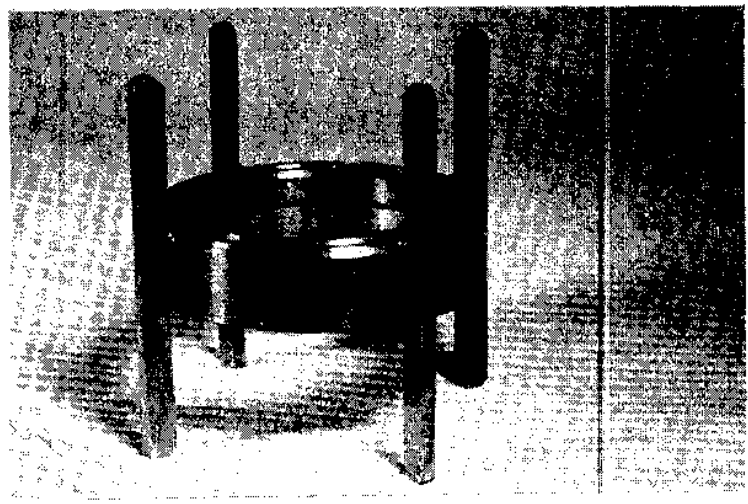

FIG. 14 RIBBED SPACER USED IN SOT-4 ASSEMBLY

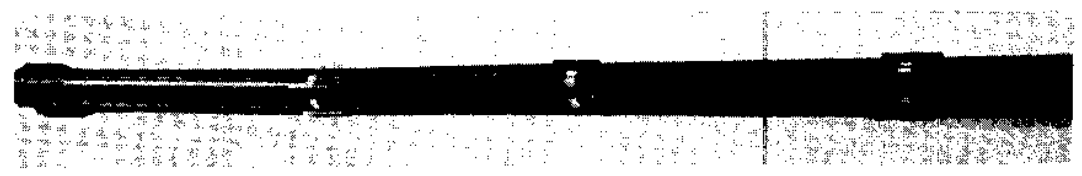

FIG. 15 PORTION OF FUEL COLUMN WITH RIBBED SPACERS ATTACHED

An assembly of seven short fuel pieces with ribbed spacers was examined after 57 days of flow testing in an out-of-reactor 10op; there was no sign of wear on the fuel or housing components. Another assembly, consisting of an integrally ribbed outer housing tube of Zircaloy, a 9-foot-long $\mathrm{UO}_{2}$ outer fuel tube, and a three-piece dummy inner fuel column, was flow tested for 97 days. The dummy inner fuel column is shown in Figure 16. Ribbed spacers similar to those used in the first assembly, shown in Figure 17, were attached to each end of the top and bottom segments of the three-piece inner column. In this test the 
FIG. 16 DUMMY INNER FUEL COLUMN

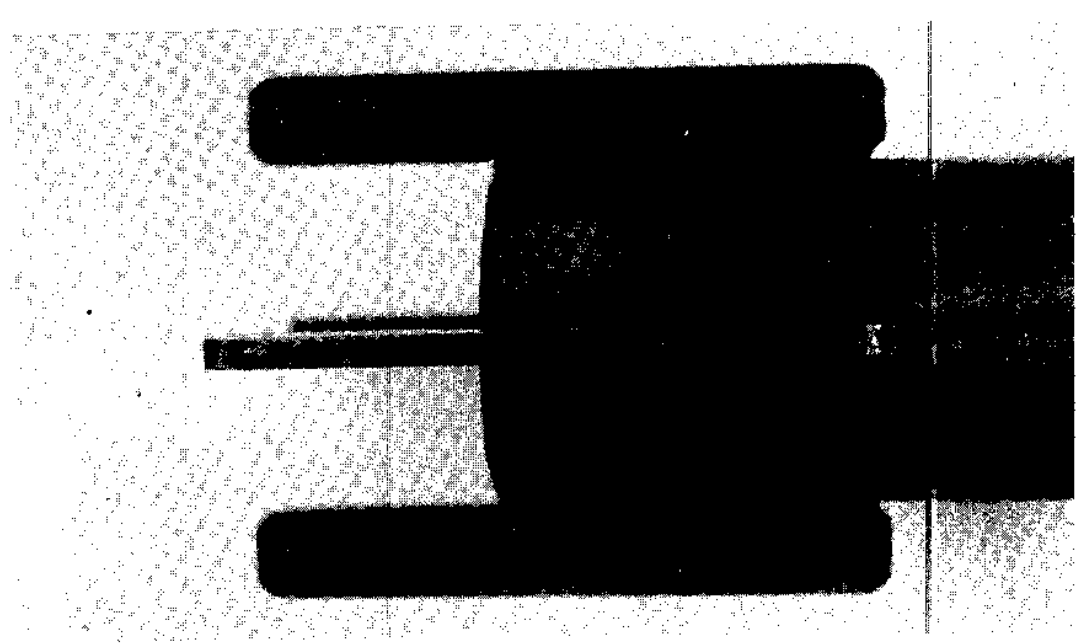

FIG. 17 RIBBED SPACER ATTACHED TO DUMMY FUEL PIECE

Zircaloy inner cladding of the outer fuel tube was penetrated by one of the ribs. The damage to the ribbed spacer, shown in Figure 18, may be compared with the damage to the inner cladding of the outer fuel tube, shown in Figure 19. The $\mathrm{UO}_{2}$ core is visible as the black material through the opening which is about $1 / 8$ inch wide and 2 inches long. The large area of severe wear on the rib corresponds to the mating surface of the fuel cladding that was not completely penetrated. The mode of failure appears to be that the relative motion of the $\mathrm{r} 1 \mathrm{~b}$ to the inner clading in both vertical and horizontal directions caused the lower end of the rib to penetrate the cladding first. Continued motion then allowed the remainder of the rib to wear through the cladding until a relatively soft area of the rib at the upper end began to wear in preference to the somewhat harder cladding. Another rib, located $90^{\circ}$ from the failure, made a visible indentation estimated to be $5 \mathrm{mils}$ deep, as shown in Figure 20. Two other ribs, located $90^{\circ}$ apart and at the next lower joint of the three-piece column, also produced visible indentations approximately 3 to 5 mils deep.

This test emphasized the importance of two requirements for ribbed spacers on an articulated fuel column: (1) the area of contact between the bearing surfaces of the ribs and the adjacent fuel surfaces must be as large as is practicable; and (2) the clearance between rib circle and adjacent component should be as small as practicable with allowance for sufficient loading clearance. 


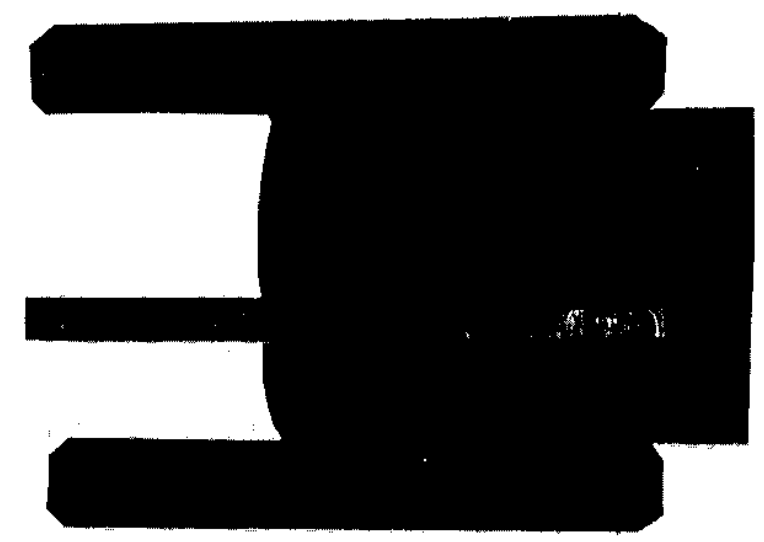

FIG. 18 DAMAGE TO RIBBED SPACER that PENETRATED CLADDING

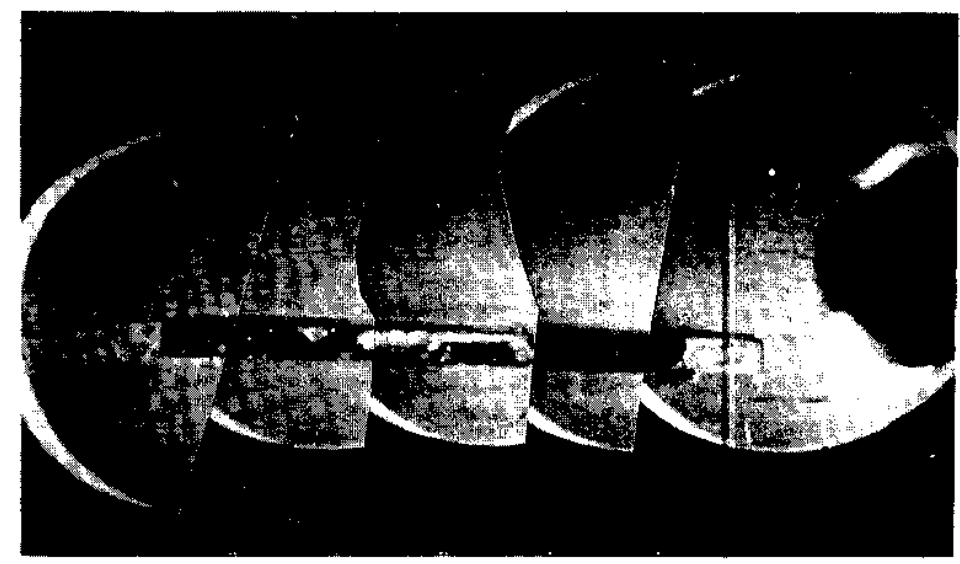

FIG. 19 FUEL TUBE FAILURE CAUSED BY RIB PENETRATION

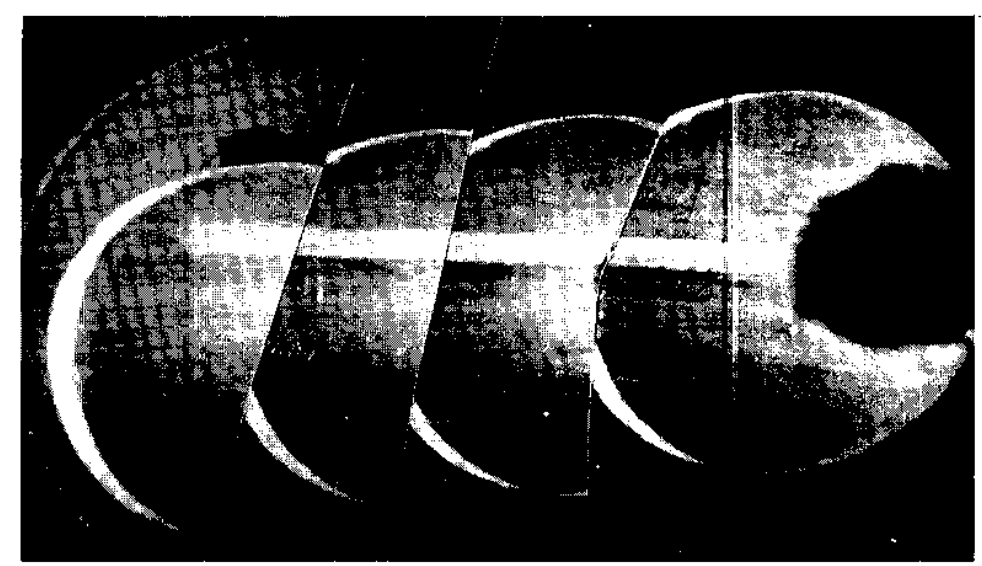

FIG. 20 CLADDING INDENTATION CAUSED BY RIBBED SPACER 


\section{Clamped-Rib Spacers}

The ultimate goal was the development of an assembly of nested full-length fuel tubes. The high cost of full-length ribs provided the impetus for the study of short spacer concepts which might be used for long tubes. Clamped-rib spacers were hydraulically tested on two fuel assemblies containing full-length nested fuel tubes.

The clamp-type spacer, shown in Figure 21, consisted of a. one-inch-long sleeve and four equally spaced ribs. The sleeve was approximately 0.050 inch thick with its mean diameter corresponding to that of the flow annulus it was to maintain. The ribs were notched to fit the sleeve and welded in position to provide an inside diameter equal to the nominal $O D$ of the fuel tube on which it was to be clamped. The outside diameter of the rib circle then provided the required clearance within the bore of the next outer fuel tube. The spacer sleeve was split at one location to allow easier positioning on the outside of the fuel tube. The ribs of the spacer were fitted snugly against the fuel tube with a standard hose clamp, and the split in the sleeve was welded. Shrinkage of the weld metal produced enough hoop tension in the sleeve to clamp the ribs tightly to the fuel tube.

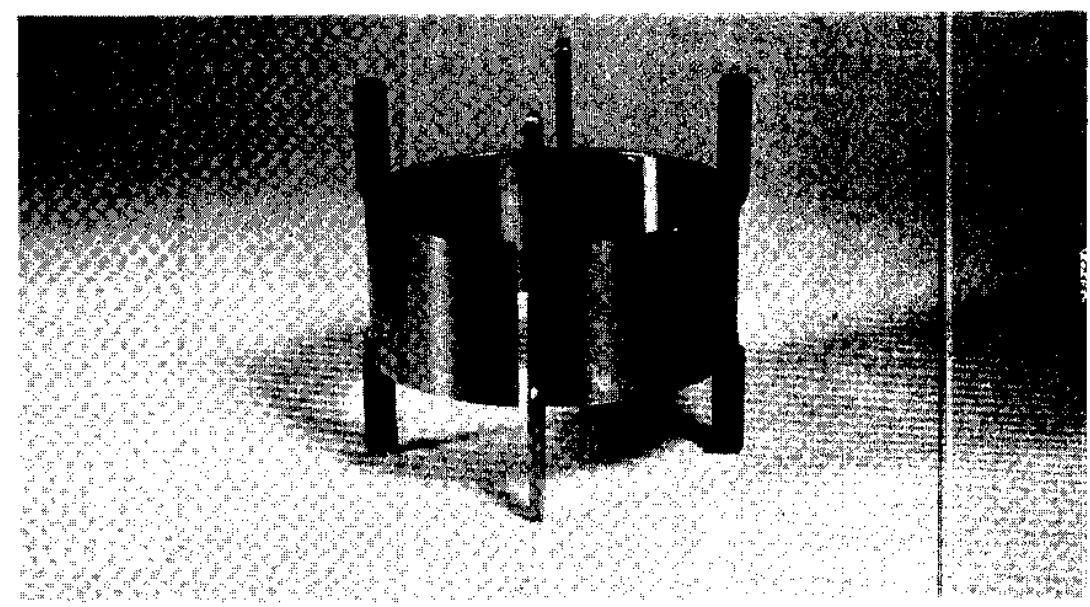

FIG. 21 CLAMPED-RIB SPACER

An assembly containing a 10-foot-long fuel tube with four clamped$r i b$ spacers along its length, shown in Figure 22, was flow tested for 97 days with no indication of damage to the fuel surface or to the bore of the Zircaloy housing. A similar assembly was flow tested for 125 days without vibration damage. 
FIG. 22 CLAMPED-RIB SPACERS POSITIONED ON FUEL TUBE

\section{STATUS}

As previously mentioned, termination of the fuel development program at Savannah River Laboratory prevented further testing that was necessary to fully evaluate the various ideas for short spacers. The development program, though not completed, showed that intermittent spacing of fuel and housing components was feasible. The concepts for ribbed spacers and clamped-rib spacers were successful in maintaining annular spacing of fuel components during out-of-reactor flow test studies. The ribbed spacers are applicable to short fuel tubes stacked in a single column, whereas the clamped-rib spacers are applicable to long fuel tubes. It is possible that both types of spacers may be required in certain applications depending on the lengths of the fuel tubes to be used. Complete evaluation of both concepts will require not only additional out-of-reactor flow tests but also irradiation tests under the reactor conditions for which the applications are intended.

\section{EFFECT OF HIGH BEARING LOADS AND VIBRATION}

Although short-length ribs, such as those in the spacer schemes just described, are applicable for an assembly of nested fuel tubes, their major limitation is the high unit bearing load to which the cladding of the adjacent fuel tube will be subjected if vibration occurs.

Examples of the effect of high unit bearing loads and vibration on Zircaloy components are shown in Figure 11, 12, 13, and 19. A more striking example of the damage resulting from the combination of these conditions was the failure of the bolling loop bayonet in the HWCTR (Figure 23).

The boiling loop bayonet, an isolated test loop in the HWCTR, consists of an upper section of stainless steel joined to a lower section of Zircaloy. The lower section is in the core portion of the reactor and houses the fuel assembly during irradiation. The fuel assembly is supported by the 15/16-inch-thick bottom end cap of the lower section. 


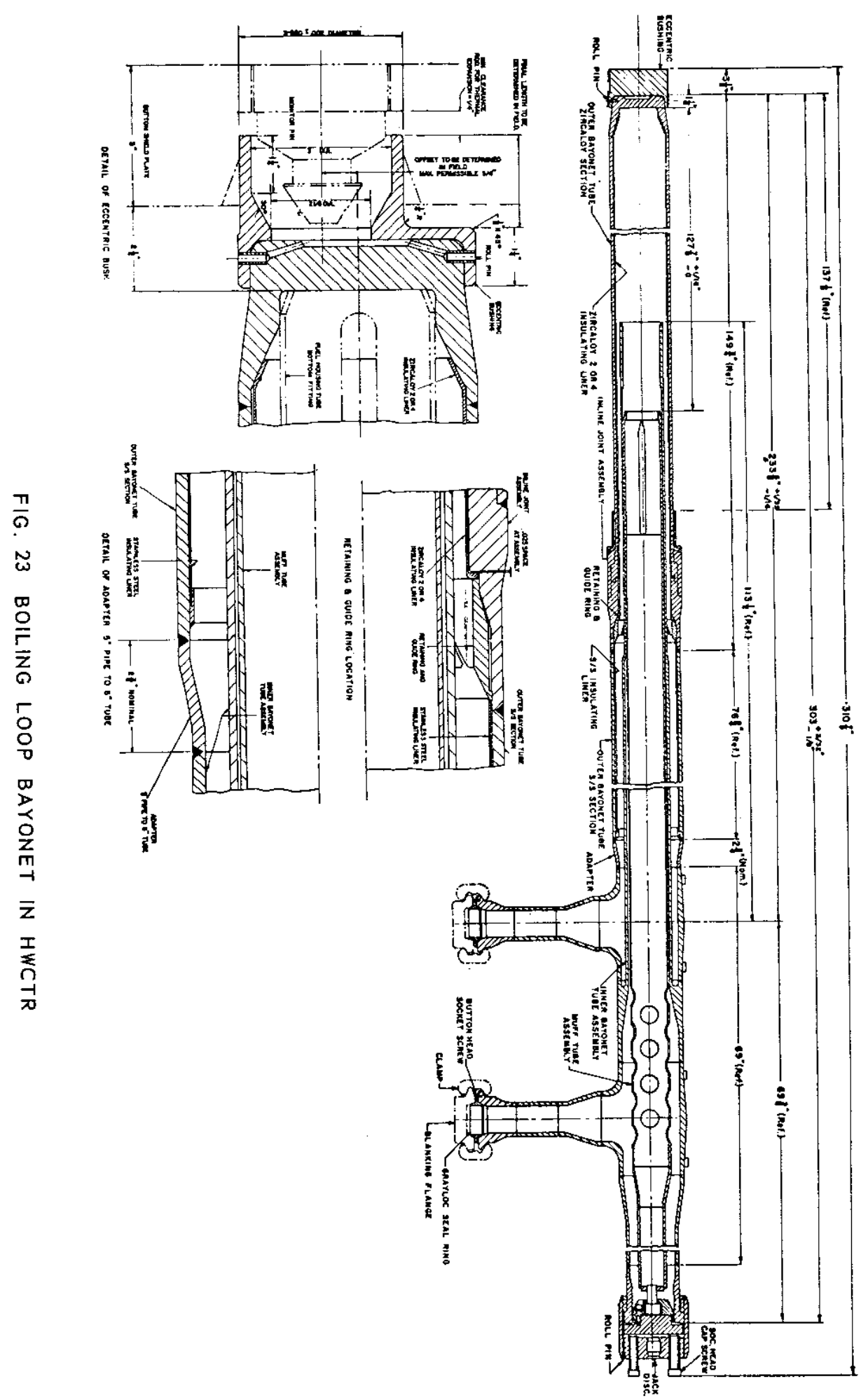


To investigate the hydraulic characteristics of the bayonet loop and also the possibility of vibration, an empty fuel element housing tube was charged to the bayonet. The housing was an integrally ribbed Zircaloy tube with a flare at each end to which stainless steel fittings were attached. The fitting at the lower end was a stainless steel cross, which supported the housing on the bottom end cap of the bayonet. The components of this fitting are shown in Figure 24.

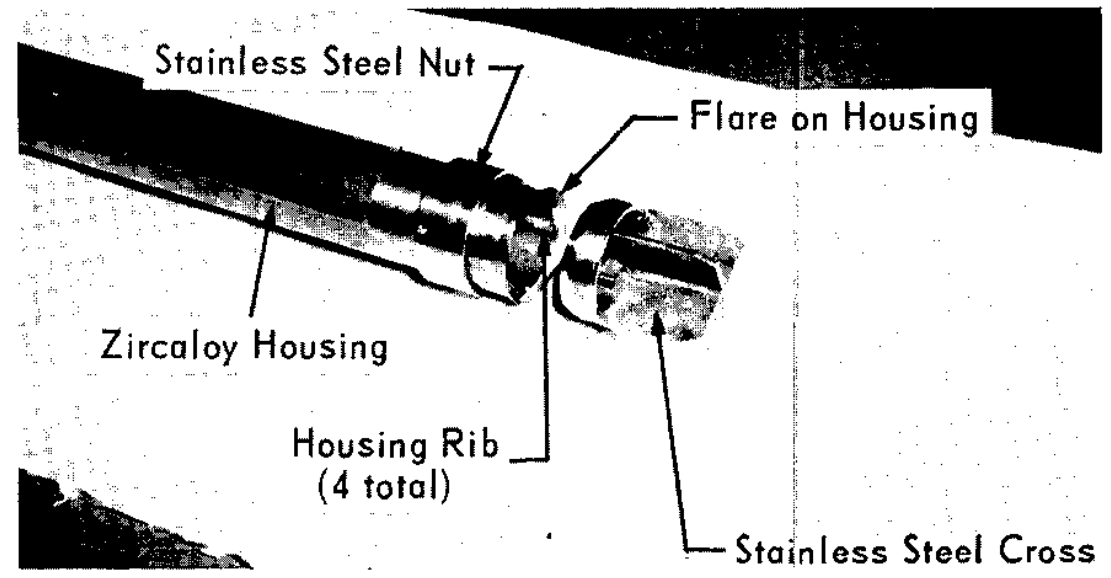

FIG. 24 COMPONENTS FOR BOTTOM FITTING OF EMPTY HOUSING IN HWCTR BAYONET

Failure of the bayonet loop was due to vibration and apparently developed as follows: the flare at the bottom of the zircaloy housing tube sheared off due to the vibration. The zircaloy housing tube then moved downward until it contacted the upper end of the support cross. Vibration caused the four legs of the cross to cut slots through the wall of the housing, allowing the housing to continue 1ts downward movement as four separate pieces. These pieces finally contacted the bottom end cap of the bayonet. As pieces of the housing subsequently broke off, the housing continued to move downward. Concurrently with the above events, the bottom fitting cross was also wearing a mating groove in the bottom of the bayonet. The inside surface of the bayonet bottom end cap is shown in Figure 25. Visible in this figure are a cross-shaped groove, which was estimated to be $5 / 8$ inch deep, and a hole extending through the remaining 5/16-inch thickness of the bayonet bottom end cap. The hole in the cap was caused by a housing tube rib that projected below the bottom of the cross and acted as a cutting tool. Presumably, the rib was energized by the vibration and was forced downward by the weight of the housing ( 20 lb). The lower end of the stainless steel cross and the projecting housing rib are shown in Figure 26. Although the cross was severely worn, its length decreased by only $1 / 8$ inch. However, the Zircaloy housing tube was 20 inches shorter than when originally charged into the bayonet. 


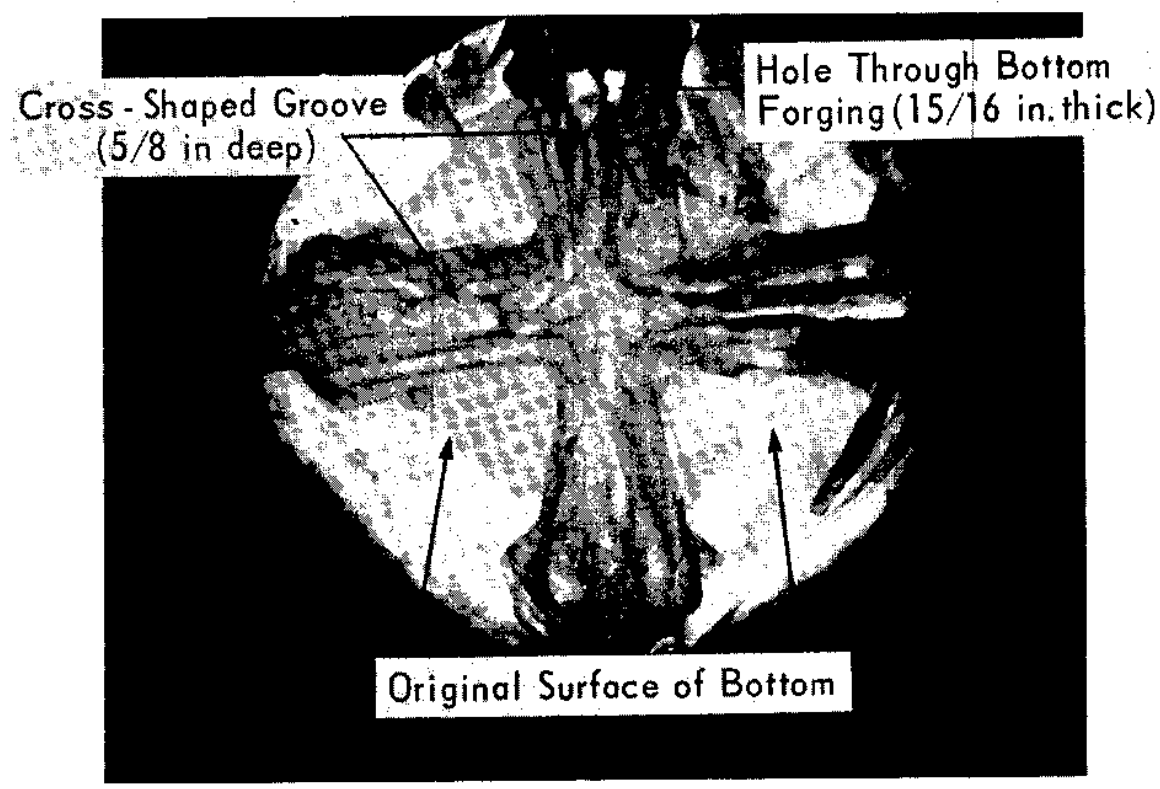

FIG. 25 DAMAGE TO BOTTOM END CAP OF HWCTR BAYONET

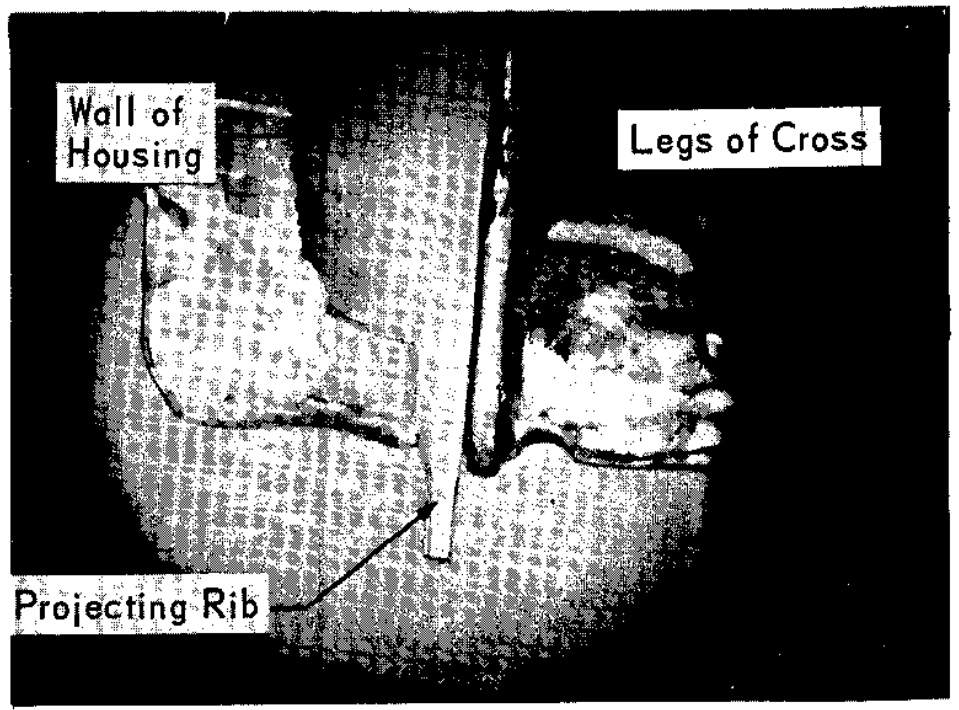

FIG. 26 HOUSING TUBE THAT PENETRATED BOTTOM OF HWCTR BAYONET 


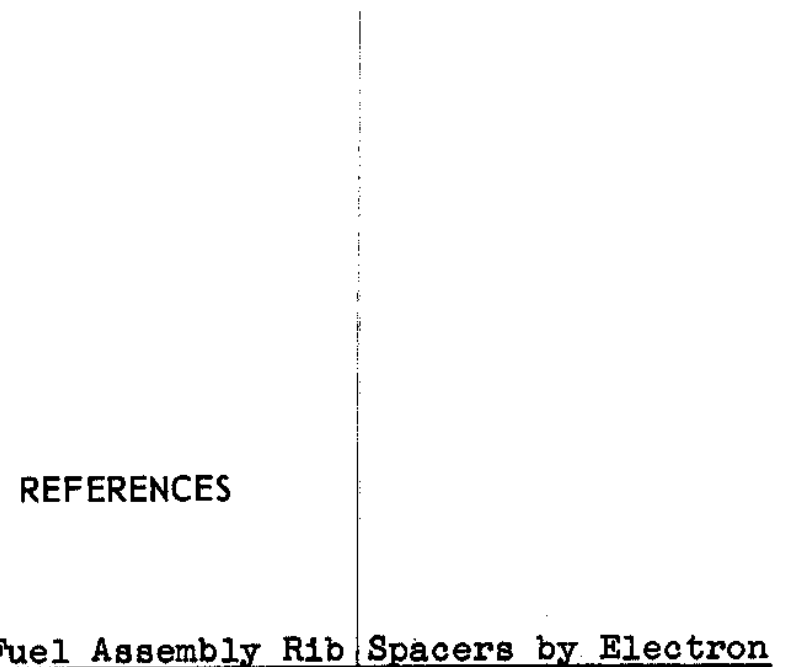

1. L. J. Scott. Attaching Fuel Assembly Rib Spacers by Electron Beam Welding. USAEC Report DP-889, E. I.

2. L. M. Arnett, et a1. Final Hazards Evaluation of the Heavy Water Components Test Reactor (HWCTR). USAEC Report DP-600, E. I. du Pont de Nemours and Co., Savannah River Laboratory, A1ken, S. C. (1962).

3. F. C. Iocke. A Periscope for Vlewing and Photographing Radioact1ve Objects Underwater. USAEC Report DP-931, E. I. du Pont de Nemours and Co., Savannah River Laboratory, A1ken, S. c. $(1964)$.

4. R. R. Hood. Heavy Water Moderated Power Reactors - Progress Report - July-August 1963. USAEC Report DP-865, E. I. du Pont de Nemours and Co., Savannah River Laboratory, Aiken, S. C. (1963). 
Description of Material

No: DP-1002

Date: $12 / 2 / 65$

Title: Fuel Spacer Development

Author: G. W. Richardson

Type of Material

Classified DP Report

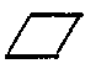

Classified Paper

$\square$

Unclassified DP Report

x

Unclassified Paper

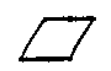

Letter

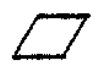

Technica I Content

Approved by /s/ E. C. Nelson Date:

$7 / 19 / 65$

Classification

Approved by Surker S. W. O'Rear Date: $12 / 2 / 65$ Authority:

Topics 800 and 850 SR00 Classification Guide

Category if DP Report

Approved by

suoter Date: $.2 / 2 / 63$ S.W. O'Rear

Final Du Pont Release Approved by coordintaing Organization Director Date: $12 / 6 / 65$

Released by:

R. G. Erdley: $/ 2 / 9 / 65$ 
AUTHOR:

Richards

CLASSIFICATION:

DATE:

DP- 1002

1. PRINT SHOP:

Reproduce Copies 2 Blackline, Pages Editor Elice Date 111760 Transmittal Letter Send to Editing: Approval copy of report Transmittal Letter

Photocopy Preliminary Distribution Transmittal Letter Master This Form

\section{Preliminary Distribution}

$28+00$
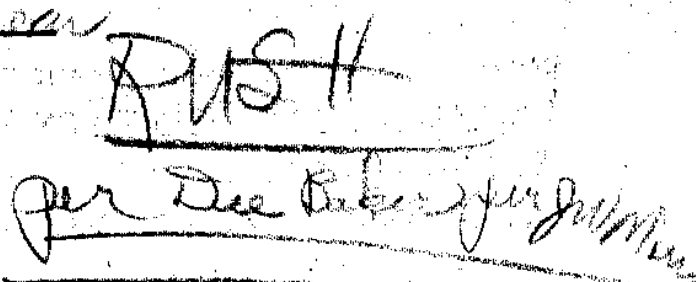

1.11

Date to Editing

2. EDITING:

Review Approval Copy and prepare Document Review and Release Forms. TO FROM

Send Approval Copy, Release Forms, and this Form to Print Shop.

3. PRINT SHOP AND DOCUMENT SECTION:

Bind and issue 12 Preliminary(blackline) Coples

Editor $4 S L$

Date $12 / 2 / 65$

Date of Preliminary Issue $12-2-65$

Send Blackline Record Copy with this Form to Editing. Date to Editing

EDITING:

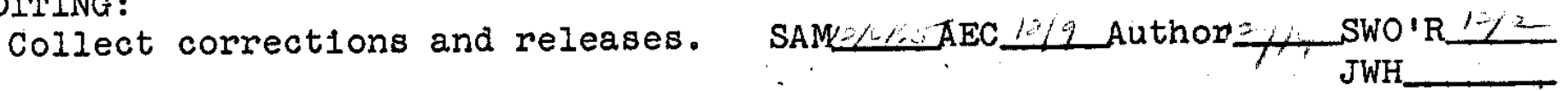

Send corrected Blackline Record Copy, corrected photocopy, Internal

Distribution Master, Transmittal Letter Master, and this Form to Print Shop.

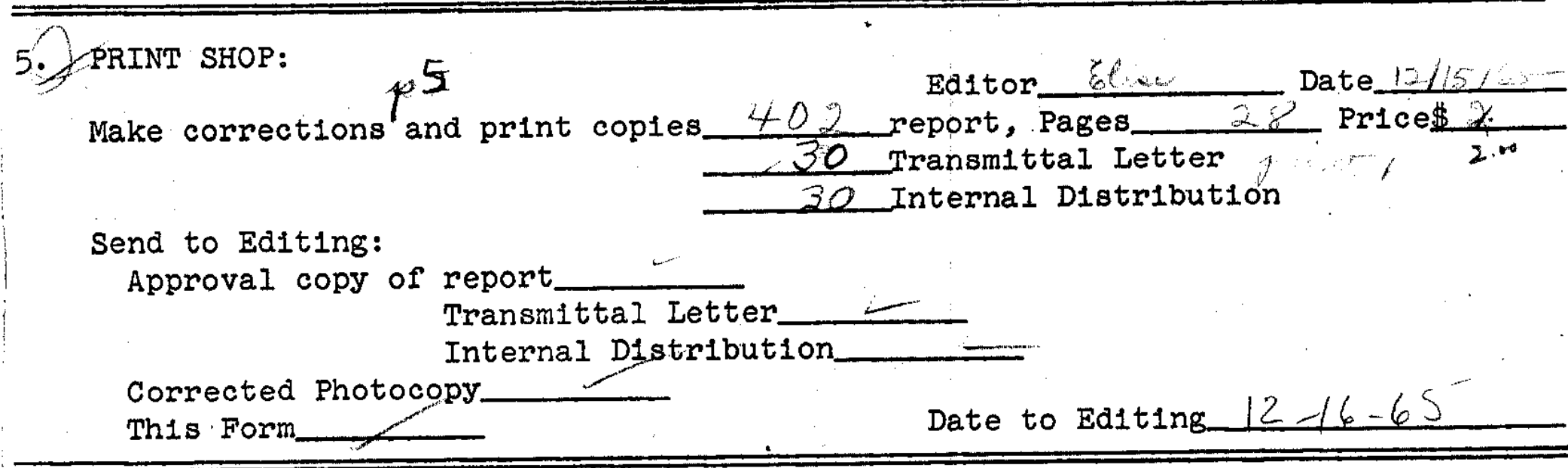




\section{EDITING :}

Review printed Record Copy. Retum printed Record Copy with Publication Forms and this Form to Print Shop.

7. PRINT SHOP AND DOCUMENT SECTION:

Bind and issue report. INTERNAL DISTRIBUTION Copies

Send to Doc. Sec. together $\rightarrow$ EXTERNAL DISTRIBUTION COPIEs TOTAL copies Editor Flin Date $12 / 16 / 65$ Send Record Copy, External Distribution List, and this Form to Editing.

Int. Issue Date $12-12-65$ Date to Editing

\section{EDITING :}

Send file folder to DP Record File, including:

File Record Copy Report Data Sheet Document Review Request for Patent Review Transmittal Ietter Preliminary Distribution TID Distribution
External Release of Tech. Info. AEC Approval Letter Publication Form DP Report Processing Form Internal Distribution. Internal References of Dotet U for B. Buker GM.P. Paidoaside, $x=5$ with etter 

DATE $3 / 65$

TO:

FROM:

INTERNAL REFERENCES FOR DP- 1002

AUTHOR George W. Richardson

TITLE

Fuel Spacer Development

List by number only (Notebooks, DPST's, or any material used in the preparation of this report).

1. $D P-889$

2. $D P-815$

3. $D P-865$

4. $0 P-885$

5. $D P-945$

6. DPST-63-435 


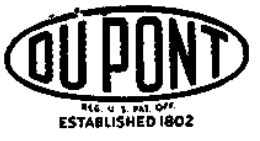

E. I. du Pont de Nemours \& Company INCORPOAATEO

SAVANNAH RIVER Laboratory

AIKEN, SOUTH CAROLINA 29802

(TWX: 803.824.0018, TEL: 803.824.6391, WU: AUGUSTA, GA.)

Mr. R. G. Erdley, Chief

Patent Branch

Savannah River Operations office

U. S. Atomic Energy Commission

Post office Box A

Alken, South Carolina

Dear Mr. Erdley:
CC: I. C. Evans - C.W. J. Wende J. W. Croach

S. A. McNe1ght

W. P. Overbeck - G. Dessauer TIS F1le

December 2, 1965

\section{REQUEST FOR PATENT REVIEW}

Please review for patent matter:

DP-1002, Fuel Spacer Development, by G.W. Richardson

If any technical clarification is needed please call J. E. Beach whose document review is attached.

Please telephone your comments to the TIS Office (Ext. 3402) and notify me by signing and returning to TIS the original of this letter. A copy is provided for your file.

If you decide to pursue a patent on any development covered, I shall be happy to supply additional information required such as appropriate references and the names of persons responsible for the development.

The above item is approved for release.

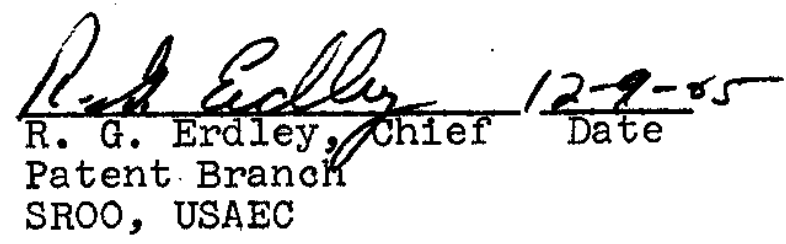

Very truly yours,

C. W. J. Wende, Director Technical Division

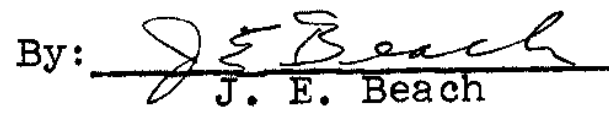




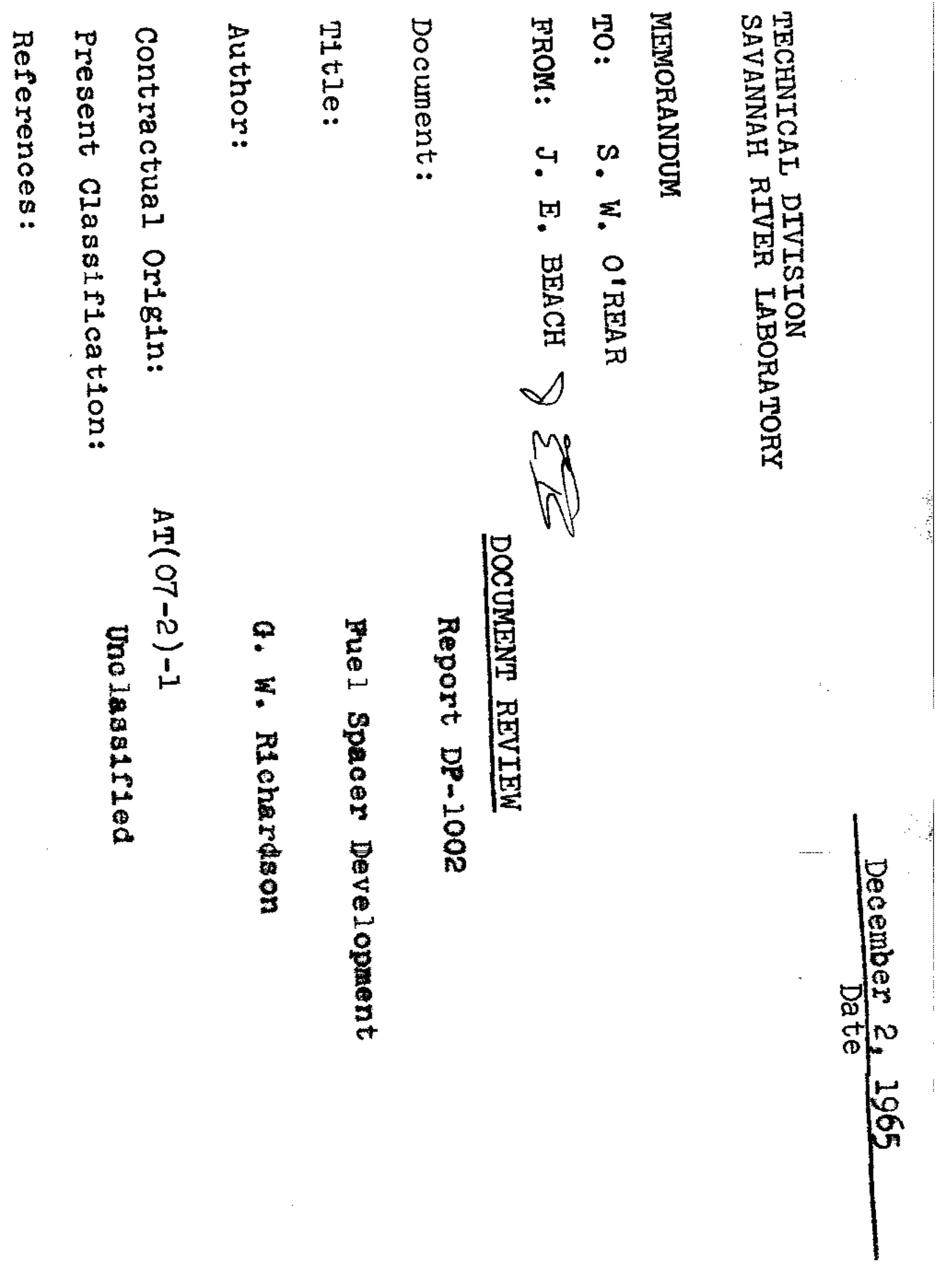


TECHNICAL DIVISION

SAVANNAH RIVER IABORATORY

MEMORANDUM

TO: S. W. O'REAR

FROM: J. E. BEACH $\nabla \sum \sum$

\section{DOCUMENT REVIEW}

Document:

Report DP-100R

Title:

Fuel Spacer Development

Author:

a. W. Richardson

Contractual Origin:

$A T(07-2)-1$

Present Classification:

Uno lassified

References:

No items were noted that, in my opinion, should be called to the attention of the AEC for patent consideration. 
INSTRUCTIONS: This form should accompany each UNCLASS IFIED document the first time it is submitted to the

USAEC Division of Technical Information Extension, Post Office Box 62, Oak Ridge, Tennessee.

Document Title_Pue 2 Specer Deve zopmont

Author(s)
Date of Document

Contract No.
Nov. 2965 An $(07-2)-1$

1. Research and Development Report Enclosed is a TID-4500 Standard Distribution Report as defined in AEC Manual Chapter 3202. No Journal Publication or Oral Presentation is Intended. (Use Section II or III below if Journal Publication is Intended or Section IV if Oral Presentation is Intended.)

1. Complete TID-4500 distribution has been made, including copies to the Clearinghouse for Federal Scientific and Technical Information, National Bureau of Standards (formerly OTS) (Federal Clearinghouse sale price is $\$$ ). The number of copies specified in TID-4500 has been forwarded to the Division of Technical Information Extension for stock and for further distribution to domestic and fore ign depository libraries, foreign exchange organizations, etc., and for announcement in Nuclear Science Abstracts.

2. $\square$ Document has been printed but complete TD-4500 distribution has not been made. Copies are being furnished for the Division of Technical Information Extension to:

a. $\square$ Make complete TID -4500 distribution including copies to Federal Clearinghouse (sale price is $\$$ __ and to depository libraries, etc.

b. $\square$ Make distribution to Federal Clearinghouse and depository libraries, etc. AEC and other Government agency distribution has been made in accordance with TID -4500 (Federal Clearinghouse sale price is $\$$ __).

c. $\square$ Other. Please specify

3. $\square$ No copies have been printed for TID -4500 and Federal Clearinghouse distribution. DTI may reproduce from copy enclosed and $\mathrm{m}$ ake TID-4500 distribution, including copies to Federal Clearinghouse for public sale, depository libraries, etc. Enclosure is:
a. $\square$ Printed copy
b. $\square$ Typed copy

c. $\square$ Reproducible or multilith plates (Up to 25 copies will be furnished to authors if desired. Indicate number .)

4. $\square$ This document, previously distributed as a classified report, has been declassified with $\square$ without $\square$ deletions. D'TI may reproduce from the ir master copy and make TID -4500 distribution, including copies to Federal Clearinghouse for public sale, and to depository libraries, etc. (Up to 25 copies will be furnished to authors if desired. Indicate number .)

11. $\square$ Document Enclosed is a TID-4500 Standard Distribution Report which is also intended for Journal Publication:

1. $\square$ TID -4500 (AEC) distribution has been made. Copies are enclosed for DTI to make single copy distribution to Federal Clearinghouse and to the domestic depository libraries, and for announcement in NSA.

2. $\square$ Copies are being furnished DTI to make TID-4500 (AEC) distribution, and single copy distribution to Federal Clearinghouse and to the domestic depository libraries, and for announcement in NSA.

3. $\square$ From the copy enclosed, DTI is requested to reproduce in Microcand form and make TID 4500 (AEC) distribution, domestic depository library distribution and send 1 full size copy to Federal Clearinghouse, and announce in NSA.

Document enclosed has or will be submitted for publication in the following scientific journal:

1II. $\square$ Document enclosed is intended for publication in a journal whose publication policy precludes advance distribution within the AEC and single copy distribution to Federal Clearinghouse and to domestic depository libraries.

1. Paper has been or will be submitted for publication in the following scientific journal:

(NOTE: DTI will hold this document for internal use and will not announce in NSA. No further distribution will be made except in unique circumstances when the report is required by present work of another AEC Contractor in advance of the paper's appearance in the journal. Such further distribution by DTI will be limited to specific requests for this information.) 
IV. $\square$ Document enclosed is intended for Oral Presentation.

Name, Location, Sponsor of Meeting

Publication plans are:

1. $\square$ This paper will be included in the published proceedings of the meeting.

2. This paper will not be included in published proceedings. After the date indicated above:

a. $\square$ DTI is requested to reproduce and make TID -4500 distribution, including copies to Federal Clearinghouse, depository libraries and announce in NSA.

b. $\square$ We (originator) will make TID -4500 distribution, including copies to Federal Clearinghouse. (Note: When printed, please transmit copies to DTI with a new PRF appropriately checked in Section I.)

c. $\square$ Paper will be submitted for journal publication. (NOTE: When paper is submitted for journal publication, please submit to DTI a new PRF appropriately checked in either Section II or III.)

V. $\square$ Document enclosed is an internal or informal report not intended for TID-4500 Standard Distribution, Journal Publication or Oral Presentation.

AEC Manual Chapter 3202 requires that informal reports generally be given TID-4500 distribution, and that technical information contained in internal reports also appear in a distributable document which receives appropriate distribution.

Chapter 3202 does recognize that issuing organizations may wish to recommend distribution limitations for informal reports and internal reports (subsequently distributed externally) under certain conditions. It also provides for negotiation between DTI and the originator, or DTI and the cognizant AEC Program Division if distribution limitations specified by the originator appear questionable to Federal Cleaxinghouse.

Recommendations are:

1. DTI is $\square$ is not $\square$ to make selected positive distribution to certain AEC contractors as appropriate.

2. DTI is $\square$ is not $\square$ to fill requests for this document from AEC contractors.

3. DTI is $\square$ is not $\square$ to selectively distribute and fill requests for this document from other Government agencies.

4. DTI is $\square$ is not $\square$ to make a single copy available to Federal Clearinghouse and announce in NSA.

IF DISTRIBUTION LIMITATIONS ARE INDICATED ABOVE, LIST JUSTIFICATION OR REASONS AS REQUIRED BY AEC MANUAL CHAPTER 3202.

Patent clearance for the document cited in this Publication Release Form has $\square$ has not $\square$ been obtained.

This release is submitted by:

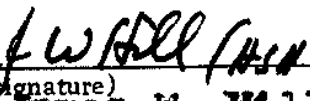

game日 W. H11

(name typed)

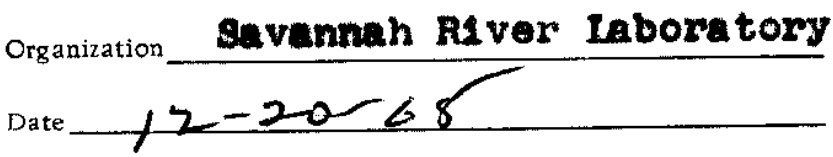

If it is desired that correspondence concerning this document be directed to an individual other than the name above, please indicate 
1. R, L, Morgan

2. R. G. Erdley

3. S. A. McNeight

4. I. C. Evans - C. W. J. Wende J. W. Croach

5. D.F. Babcock

6. I. W. FOX

7. W. P. Overbeck - A. A. Johnson J. O. Morrison

8. J.W. Morris

9. E. C. Nelson

10. D. Baker, Jr.

11. G. W. Richardson

$\rightarrow 12$. TIS File Record Copy
SROO, Aiken, S. C.

Wilmington AED

II

"

Savannah River Plant

Savannah River Laboratory 


\section{INTERNAL DISTRIBUTION}

1-3. P. J. Hagelston

4. H. F. Carroll

5. L. Squires - M. H. Wahl

6. S. A. McNeight

7. M. H. Smith - W. H. Holstein J. B. Tinker

8. L. C. Evans - C. W. J. Wende J. W. Croach

9. D. F. Babcock

10. W. B. Delong

II. R. R. Hood

12. W File

13. A. E. Daking

14. J. A. Monier - F. H. Endorf

15. W. P. Bebbington

16. L. W. Fox

17. J. P. Maloney

18. E. O. Kiger

19. W. P. Overbeck - A. A. Johnson

20. J. O. Morrison

21. J. E. Beach

22. J.W. Morris

23. E. C. Nelson

24. I. M. Arnett

25. P. L. Gray

26. A. F. Wright

27. V. Whatley

28. D. Baker, Jx.

29. G. W. Richardson

30. TIS File Record Copy
SROO, Aiken, S. C.

Declassification Branch

USAEC, Oak Rldge, Tenn.

$\underset{\|}{\text { Wilmington AED }}$

$$
\begin{aligned}
& n \\
& n \\
& 11 \\
& n \\
& n \\
& n
\end{aligned}
$$

Engineering Department

Savannah River Plant

"1

"1

i1

Savannah River Laboratory 


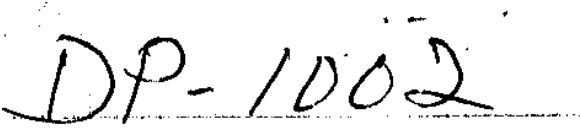

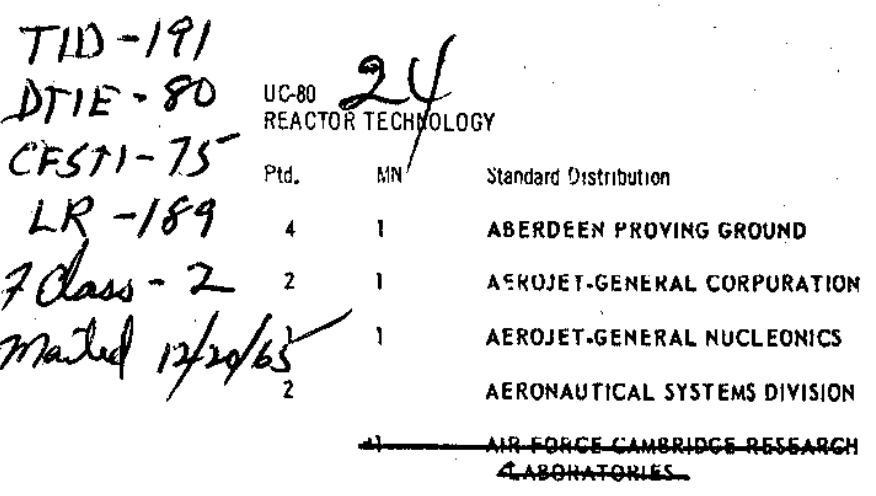

\begin{tabular}{|c|c|c|}
\hline 1 & 1 & AIR FORCE INSTITUTE OF TECHNOLOGY \\
\hline 1 & & AIR FORCE SUKGEON GENERAL \\
\hline 2 & & AIR FORCE WEAPONS LABORATORY \\
\hline 1 & & ALBUQUERQUE OPERATIONS OFFICE \\
\hline 1 & & ALLIS.CHALMERS MANUFACTURING COMPANY \\
\hline 1 & 1 & $\begin{array}{l}\text { ALLIS-CHALMERS MANUFACTURING COMPANY, } \\
\text { BETHESDA }\end{array}$ \\
\hline 1 & & ALLISON DIVISION-GMC \\
\hline 10 & 3 & ARGONNE NATIONAL LABORATORY \\
\hline 1 & 1 & $\begin{array}{l}\text { ARMED FORCES RADIOBIOLOGY RESEARCH } \\
\text { INSTITUTE }\end{array}$ \\
\hline 2 & & $\begin{array}{l}\text { APMY CHEMICAL RESEARCH AND DEVELOPMEN } \\
\text { LARORATORIES }\end{array}$ \\
\hline
\end{tabular}

1 ARMY ELECTRONICS LABORATORIES

1 ARMY ENGINEER RESEARCH AND DEVELOP. MENT LAGORATORIES

1

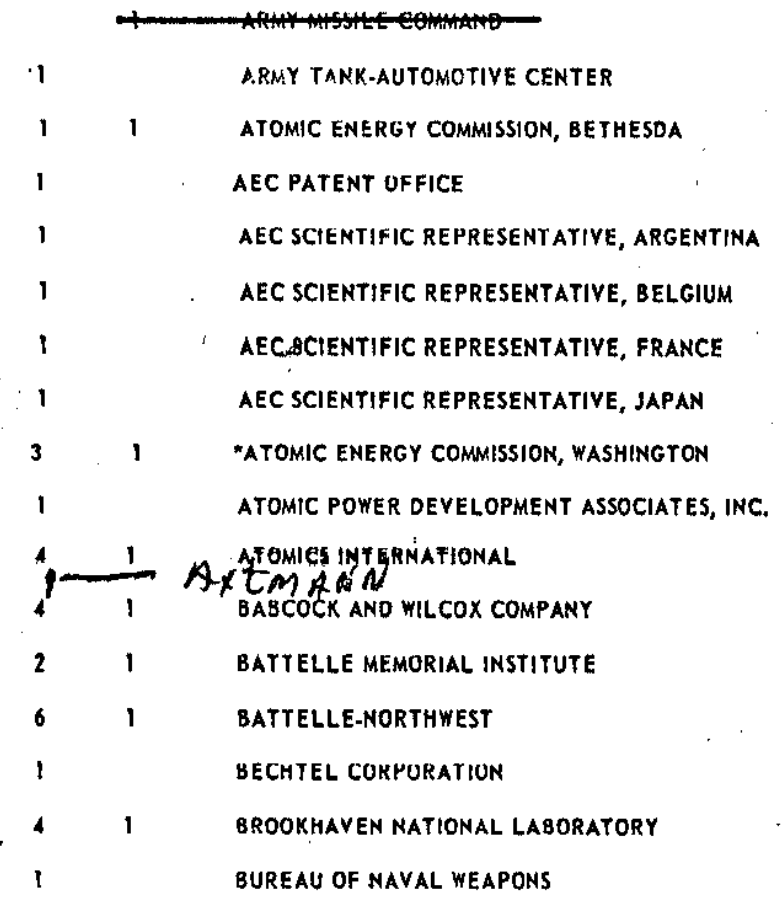

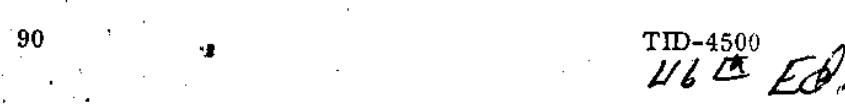

Ptd. MN Standard Distribution

1 BUREAU OF SHIPS (CODE 1500)

1 BUREAU OF YARDS AND DOCKS

CA rroudo Patent GROUP

$i$ COLUMBIA UNIYERSITY (NYO-187)

11 COMBUSTION ENGINEERING, INC.

1 . 1 COMBUSTION ENGINEERING, INC. (NRD)

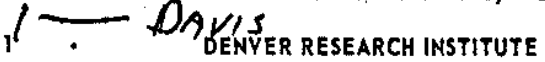

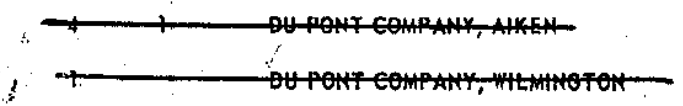

1 EDGERTON, GERMESHAUSEN AND GRIER, INC. LAS VEGAS

1 EDGEWUUD AKSENAL

i f. FRANKFORD ARSENAL

1 FRANKLIN INSTITUTE RESEARCH LABORATORIES

i : FUNDAMENTAL METHODS ASSOCIATION

21 GENERAL ATOMIC DIYISION

2 GENERAL DYNAMICS/FORT WORYH

31 GENERAL ELECTRIC COMPANY, CINCINNATI

1 GenERAL ELECTRIC COMPANy, PLEASANTON

$1 \quad 1$ GENERAL ELECTRIC COMPANY, SAN JOSE

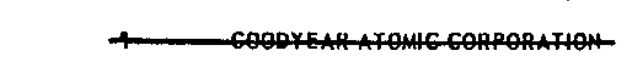

1 HUGHES AIRCRAFT COMPANY

1 IIT RESEARCH INSTITUTE

21 IOWA STATE UNIVERSITY

2 JET PROPULSION LABORATORY

${ }^{2}+1$ KANOLLS GTOMIC POWER LABORATORY

1 LOCKHEED-GEORGIA COMPANY

1 LOCKHEED MTSSILES AND SPACE COMPANY (NASA)

2 LOS ALAMOS SCIENTIFIC LABORATORY

MARE ISLAND NAYAL SHIPYARD
1
1




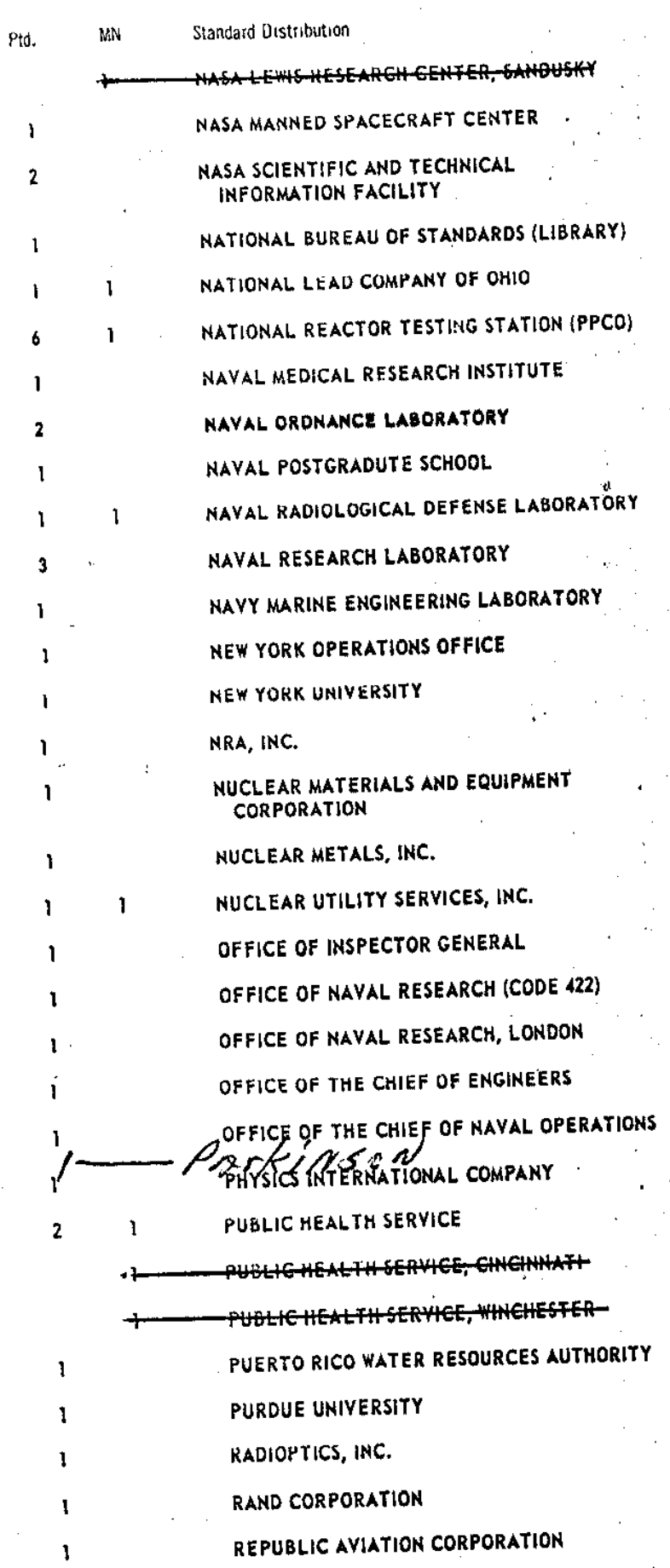

\begin{tabular}{|c|c|}
\hline$M N$ & Staridard Distribution \\
\hline & $\begin{array}{l}\text { REYNOLDS ELECTRICAL AND ENGINEERING } \\
\text { COMPANY, INC. }\end{array}$ \\
\hline & ROCKY MOUNTAIN ARSENAL \\
\hline & SAN FRANCISCO OPERATIONS OFFICE \\
\hline & SANDIA CORPORATION, ALBUQUERQUE \\
\hline & SCHENECTADY NAYAL. REACTORS OFFICE \\
\hline & SCHOOL OF AEROSPACE MEDICINE \\
\hline & SOUTHERN NUCLEAR ENGINEERING, INC. \\
\hline & SOUTHWEST RESEARCH INSTITUTE : \\
\hline & TENNESSEE VALLEY AUTHORITY \\
\hline & TODD SHIPYARDS CORPORATION \\
\hline & $\begin{array}{l}\text { TRW SPACE TECHNOLOGY LABORATORIES } \\
\text { (NASA) }\end{array}$ \\
\hline 1 & UNION CARBIDE CORPORATION (ORGDP) \\
\hline $\begin{array}{r}2 \\
+\end{array}$ & UNION CARBIDE CORPORATION (ORNL) \\
\hline 1 & UNITED NUCLEAR CORPORATION (NDA) \\
\hline & U. S. PATENT OFFICE \\
\hline 1 & UNIVERSITY OF CALIFORNIA, BERKELEY \\
\hline 1 & UNIVERSITY OF CALIFORNIA, LIVERMORE \\
\hline 1 & UNIVERSITY OF PUERTO RICO \\
\hline 1 & UNIVERSITY OF ROCHESTER \\
\hline & UNIVERSITY OF ROCHESTER (KAPLON) \\
\hline & WALTER REED ARMY MEDICAL CENTER \\
\hline ! & $\begin{array}{l}\text { WESTINGHOUSE BETTIS ATOMIC POWER } \\
\text { LABORATORY }\end{array}$ \\
\hline 1 & WESTINGHOUSE ELECTRIC CORPORATION \\
\hline & $\begin{array}{l}\text { WESTINGHOUSE ELECTRIC CORPORATION } \\
\text { (NASA) }\end{array}$ \\
\hline & WHITE SANDS MISSILE RANGE \\
\hline & $\begin{array}{l}\text { DIVISION OF TECHNICAL INFORMATION } \\
\text { EXTENSION }\end{array}$ \\
\hline & $\begin{array}{l}\text { CLEARINGHOUSE FOR FEDERAL SCIENTIFIC } \\
\text { AND TECHNICAL INFORMATION }\end{array}$ \\
\hline & (1) \\
\hline & Deletions from the Last Edition \\
\hline
\end{tabular}

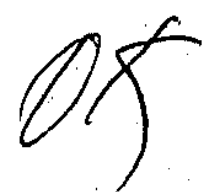

*New listing $\alpha$ change in old listing. 